\title{
Valorizzazione del patrimonio immateriale attraverso le tecnologie digitali: la Passione di Sordevolo
}

\author{
Massimiliano Lo Turco \\ Elisabetta Caterina Giovannini \\ Andrea Tomalini
}

Abstract

Gli Stati membri dell'UNESCO definiscono il patrimonio culturale immateriale (ICH) come l'insieme di pratiche, rappresentazioni, espressioni, nonché conoscenze e abilità che le comunità, i gruppi e, in alcuni casi, gli individui riconoscono come parte integrante del loro patrimonio culturale.

Il Museo della Passione di Sordevolo protegge, conserva e diffonde il valore culturale e sociale della più grande rappresentazione popolare cristiana in Italia, denominata "La Passione di Sordevolo", che con cadenza quinquennale dal 1816 a oggi rievoca la Passione di Cristo, coinvolgendo gran parte degli abitanti di Sordevolo e dintorni.

Il contributo presenta alcuni esiti della ricerca del progetto di modellazione ricostruttiva e storytelling visuale denominato 'Digital historical scenic design'. Il progetto esplora l'utilizzo delle tecnologie digitali per la creazione di nuovi linguaggi di espressione e produzione creativa, attraverso la rielaborazione del patrimonio documentario (fotografie, schizzi, disegni) e la raccolta sistematica della tradizione orale tramandata di generazione in generazione ai membri della comunità locale. L'uso di differenti strategie narrative ha consentito di ricreare virtualmente parte dell'esperienza della Passione messa in scena nel 1934 e nel 1950. Una forma di teatro popolare che merita di essere tutelata e divulgata anche attraverso i media digitali, ancor più in un periodo in cui ogni attività in presenza è sospesa a causa della pandemia tuttora in atto.

Parole chiave

modellazione digitale ricostruttiva, storytelling, teatro popolare, patrimonio culturale immateriale.

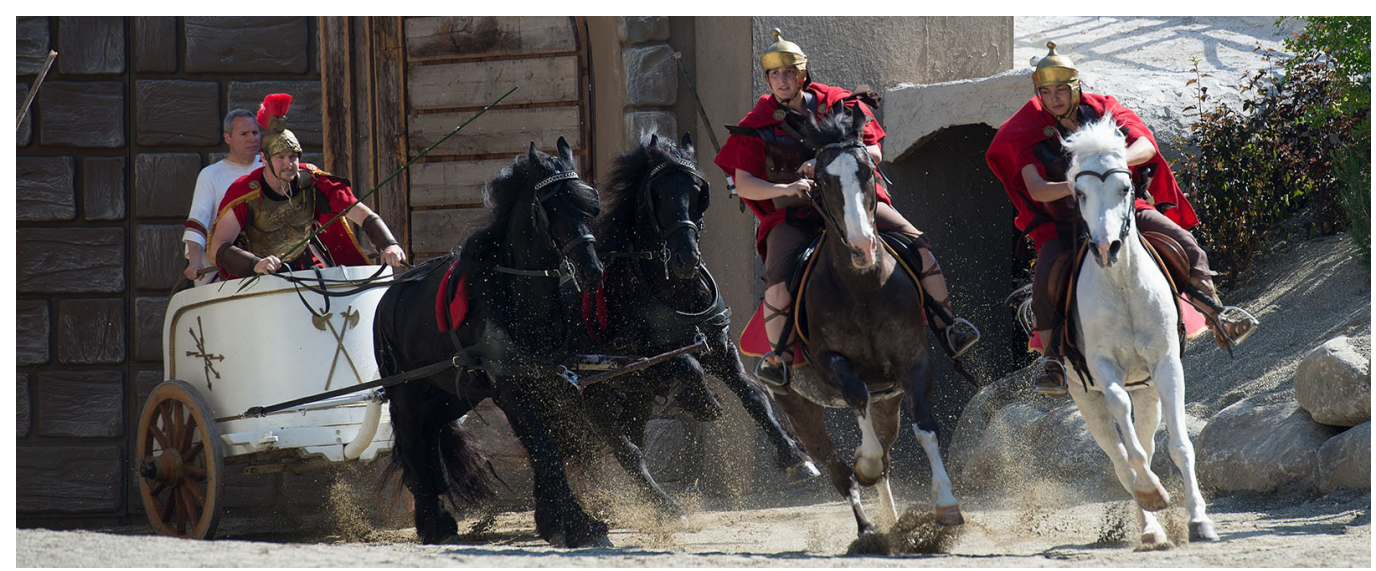




\section{Introduzione}

II termine patrimonio culturale immateriale è l'esito di molteplici iniziative che ne hanno plasmato il significato con una definizione che considera tale patrimonio non più come mera espressione culturale quanto piuttosto come un processo dove identità culturale, tradizione e conoscenza coesistono e permangono grazie alle proprie comunità di riferimento.

A partire dal 1952 il termine utilizzato per indicare questo tipo di patrimonio culturale è stato "folklore", definito nel 1989 come cultura tradizionale e popolare riconosciute come rispondenti alle aspettative della comunità in quanto espressione della sua identità culturale e sociale, delle norme e dei valori che si trasmettono oralmente, per imitazione o in altri modi. A seguito della Raccomandazione per la Salvaguardia della Cultura e del Folklore ( 1989), si valuta di primaria importanza la salvaguardia di tale patrimonio che, con la Conferenza Generale dell'UNESCO di Parigi ( 1998) viene denominato Patrimonio Intangibile e a cui farà seguito la Proclamazione dei Capolavori del Patrimonio Orale e Immateriale dell'Umanità [Alivizatou 2007]. Questa iniziativa mirava all'individuazione di spazi permanenti e di forme di espressione culturale popolari e tradizionali che meritavano di essere proclamati simboli del patrimonio orale, poiché costituivano "exceptional examples of freedom and diversity of cultural expression, of social interaction, tolerance and cultural understanding, of the preservation of the collective memory, of the education of youth, of the oral transmission of universal values, of exchanges among generations and of urban integration" [I].

Numerose forme di espressione culturale e di spazi culturali appartenenti a settanta diversi Paesi ricevettero un riconoscimento a seguito di tre diverse proclamazioni (200I, 2003 e 2005): per la prima volta le comunità locali vennero investite del ruolo di custodi della tradizione con il compito di salvaguardia del loro patrimonio immateriale, promuovendone il loro coinvolgimento attivo nella trasmissione delle proprie tradizioni alle generazioni future. A partire dal 2003, con l'entrata in vigore della Convenzione per la salvaguardia del patrimonio culturale intangibile, sono stati individuati cinque domini attraverso cui il patrimonio culturale immateriale si manifesta:

I. Tradizioni orali ed espressioni, incluso il linguaggio come veicolo del patrimonio culturale immateriale.

2. Arti dello spettacolo.

3. Pratiche sociali, rituali ed eventi festivi.

4. Conoscenza e pratiche riguardanti la natura e l'universo.

5. Artigianato tradizionale.

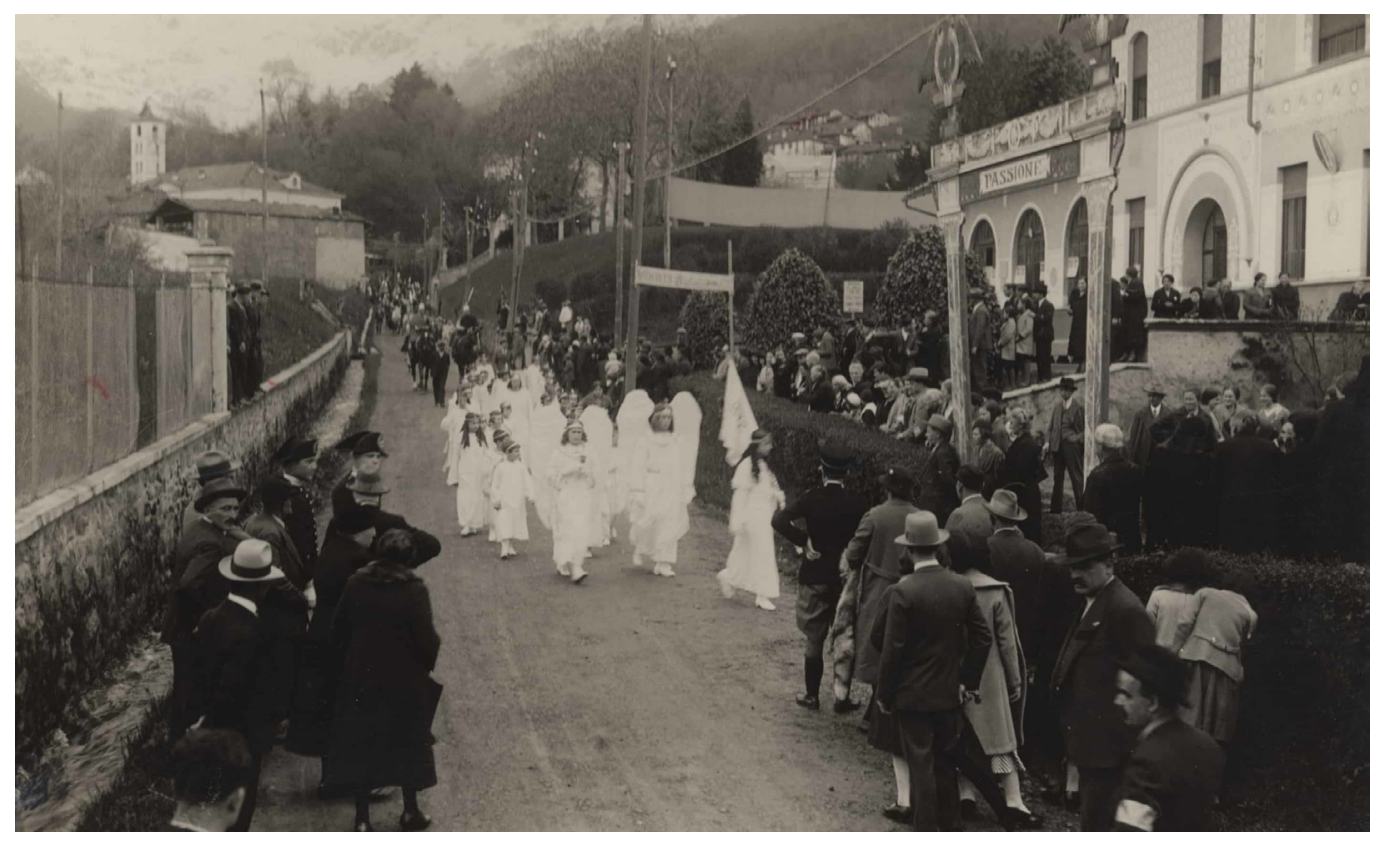


La rappresentazione della Passione di Sordevolo è pienamente ascrivibile ad alcuni di questi domini: il patrimonio immateriale da conservare non è la singola manifestazione culturale in sé, ma anche il sapere e la conoscenza che vengono trasmessi di generazione in generazione e fatti rivivere nei secoli dalla comunità sordevolese. Un valore culturale che oggi viene riconosciuto dalla comunità locale come parte integrante del proprio patrimonio culturale e che necessita di tutela dei processi di produzione artistica dello spettacolo stesso affinché possa plasma la memoria collettiva [Bortolotto 2007]. Comunicare questo tipo di patrimonio significa traguardare le normali strategie museografiche che tendono a trasformare il patrimonio intangibile in una forma tangibile per poterla conservare, archiviare e comunicare.

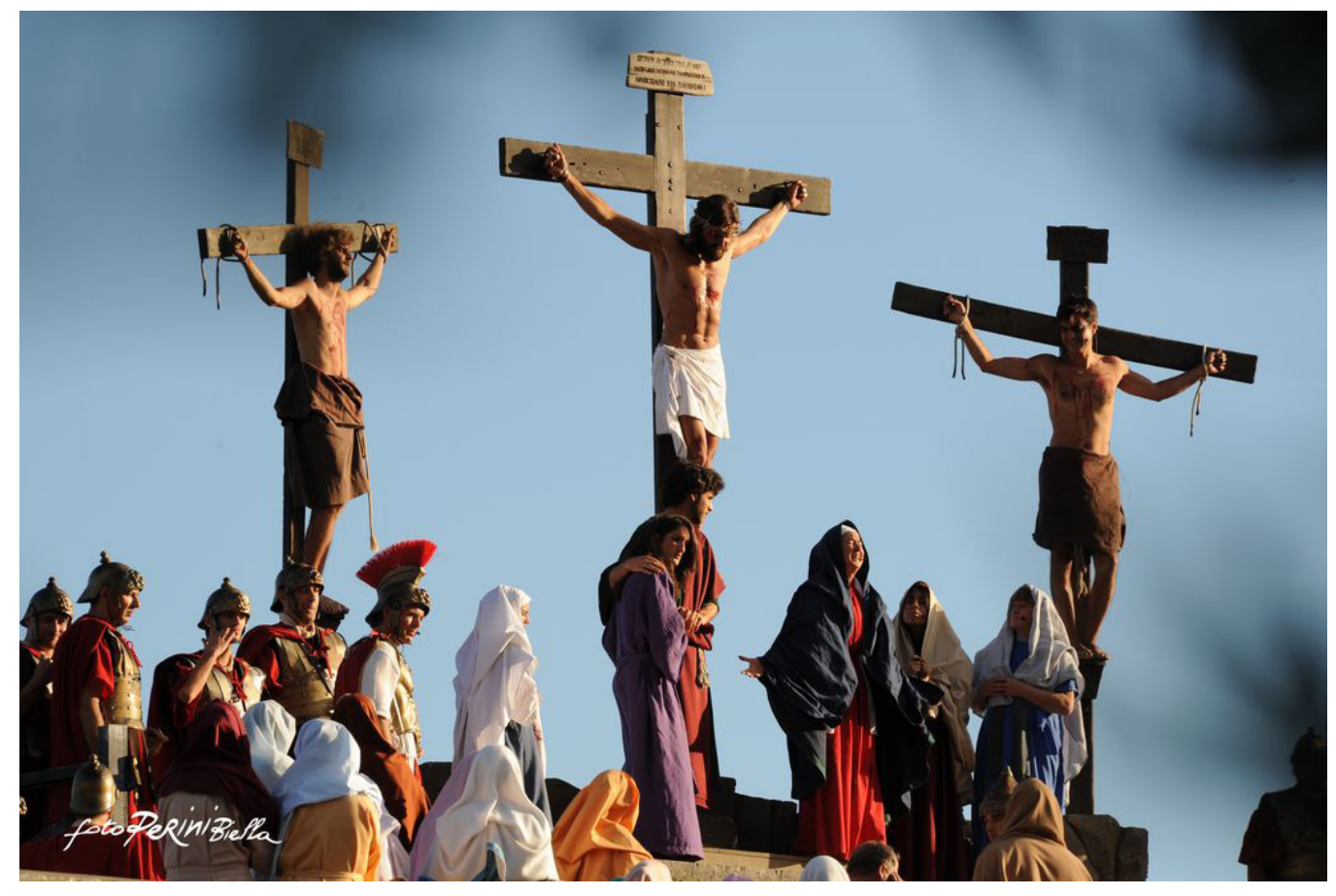

\section{Lo storytelling digitale}

Con l'avvento delle tecnologie digitali, di internet e dei social media, i musei si misurano quotidianamente con nuove sfide atte a preservare e promuovere il patrimonio culturale utilizzando nuovi linguaggi e narrazioni inedite. Se da un lato, i grandi musei sono tra gli enti che hanno maggiormente investito in un tipo di comunicazione multicanale e multipiattaforma, evidenziando come gli stessi curatori museali stiano diventando ottimi comunicatori [Bonacini 2020], dall'altra le piccole realtà faticano a strutturare strategie comunicative efficaci. La pandemia COVID- 19 ha inoltre evidenziato come la trasformazione digitale del settore culturale sia più che mai necessaria per riconoscere al nostro patrimonio la dignità di servizio essenziale per il cittadino, al pari di sanità e scuola, così come auspicato dal Decreto Colosseo n. I46/20I5.

Nel volume I musei e le forme dello storytelling digitale Bonacini esamina criticamente varie tipologie di storytelling digitale a oggi riconducibili all'ambito dei beni culturali e che si basa principalmente sulla suddivisione in tre tipologie di coinvolgimento: esperienza, interazione, attrazione [Viola 2017].

In particolare, le esperienze descritte evidenziano che il processo di democratizzazione della cultura sia ancora incompleto e propone nuove forme di fruizione in cui le tecnologie digitali possano ridurre il digital divide tra il mondo scientifico e la comunità. Lo stesso approccio è applicabile all'ambito della comunicazione della ricerca e all'utilizzo di strumenti di public engagement per le comunità accademiche ed enti di ricerca pubblici e privati. $\grave{E}$ quanto mai opportuno interrogarsi sui reali benefici di questa democratizzazione della 
cultura dove l'utente diventa co-creatore di conoscenza e di nuovi contenuti digitali. Se da un lato emerge l'esigenza, non solo socio-culturale ma anche economica, di trovare nuove narrazioni per veicolare contenuti culturali, dall'altra il rischio è un livellamento intellettuale delle pratiche di ricerca che sottendono la creazione di questi contenuti.

Diventa inoltre evidente l'ambiguità tra la creazione di contenuti a scopo divulgativo e la creazione di contenuti utili a valorizzare e accreditare autorevolmente i risultati raggiunti dalla ricerca per i diversi fruitori interessati.

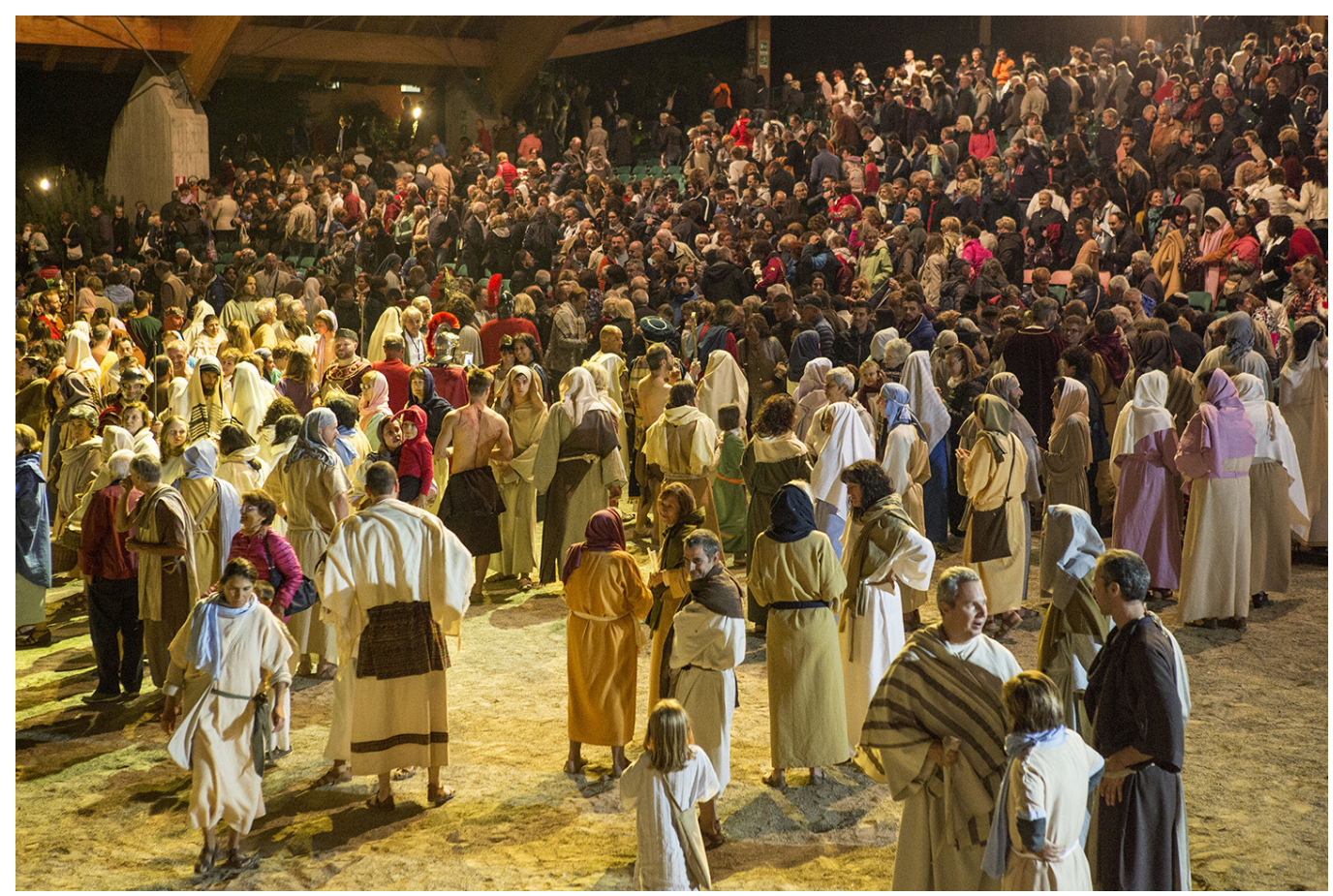

\section{Il caso studio: la Passione di Sordevolo}

Situato nella valle dell'Elvo, una terra naturale ai piedi delle Alpi, il comune piemontese di Sordevolo può essere considerato un luogo di fede e devozione popolare, le cui espressioni più emblematiche sono le sette chiese e la rappresentazione della Passione con i suoi due secoli di storia. Nel 1815 gli abitanti del villaggio fecero il voto di rappresentare la commedia ogni 5 anni se fossero stati risparmiati dalla peste che stava devastando il paese. Da quella data, il testo della Passione di Sordevolo utilizzato è la versione prodotta nel I 500 da Giuliano Dati, un cappellano della chiesa dei Santi Martiri in Trastevere, a Roma. Egli scrisse le battute dell'opera in una forma di italiano arcaico chiamata Laudi usata per la Via Crucis in scena ogni Venerdi Santo al Colosseo, anche nota come Devozione del Colosseo. Quella rappresentazione si distingueva per la grande affluenza di pellegrini, viaggiatori e personaggi famosi ma nel I 539 venne proibita da Papa Paolo III a causa del drammatico periodo della Riforma e del successivo distacco di Lutero, Calvino e altri movimenti religiosi dalla Chiesa Cattolica Romana.

Le prime rappresentazioni della Passione vennero svolte in diversi luoghi del paese di Sordevolo (fig. I) ma oggi la rappresentazione va in scena in uno spazio aperto di circa 4.000 metri quadrati dove viene allestito un angolo ricostruito di Gerusalemme, risalente al 33 d.C. La scenografia comprende il Palazzo di Erode, il Sinedrio, il Praetorium di Ponzio Pilato, l'Orto degli ulivi, il Cenacolo, il Calvario. La scenografia, realizzata interamente con i mezzi e le capacità dei cittadini, viene preparata nei minimi dettagli, con musiche appropriate, coreografie eccezionali e di rara bellezza (fig. 2). 
La rappresentazione, della durata di tre ore, consiste in un prologo e 29 scene. Lo spettacolo coinvolge l'intera comunità per un arco temporale di circa due anni: circa 400 abitanti partecipano allo spettacolo, mentre altri 300 collaborano a vario titolo dietro le quinte, realizzando i costumi, progettando e costruendo il set. Molti ruoli specifici - interpretati da cittadini comuni, non da attori professionisti - si tramandano di generazione in generazione (Gütermann 2019). L'evento sordevolese non si riduce a un'unica rappresentazione ma viene riproposto per un'estate intera, con circa 40 repliche distribuite in un arco temporale di circa tre mesi. E una tradizione che supera il momento teatrale per diventare evento culturale, sociale ed economico che integra tutta la comunità: per queste caratteristiche la Passione di Sordevolo è da considerarsi come un unicum nel panorama del folklore italiano (fig. 3).
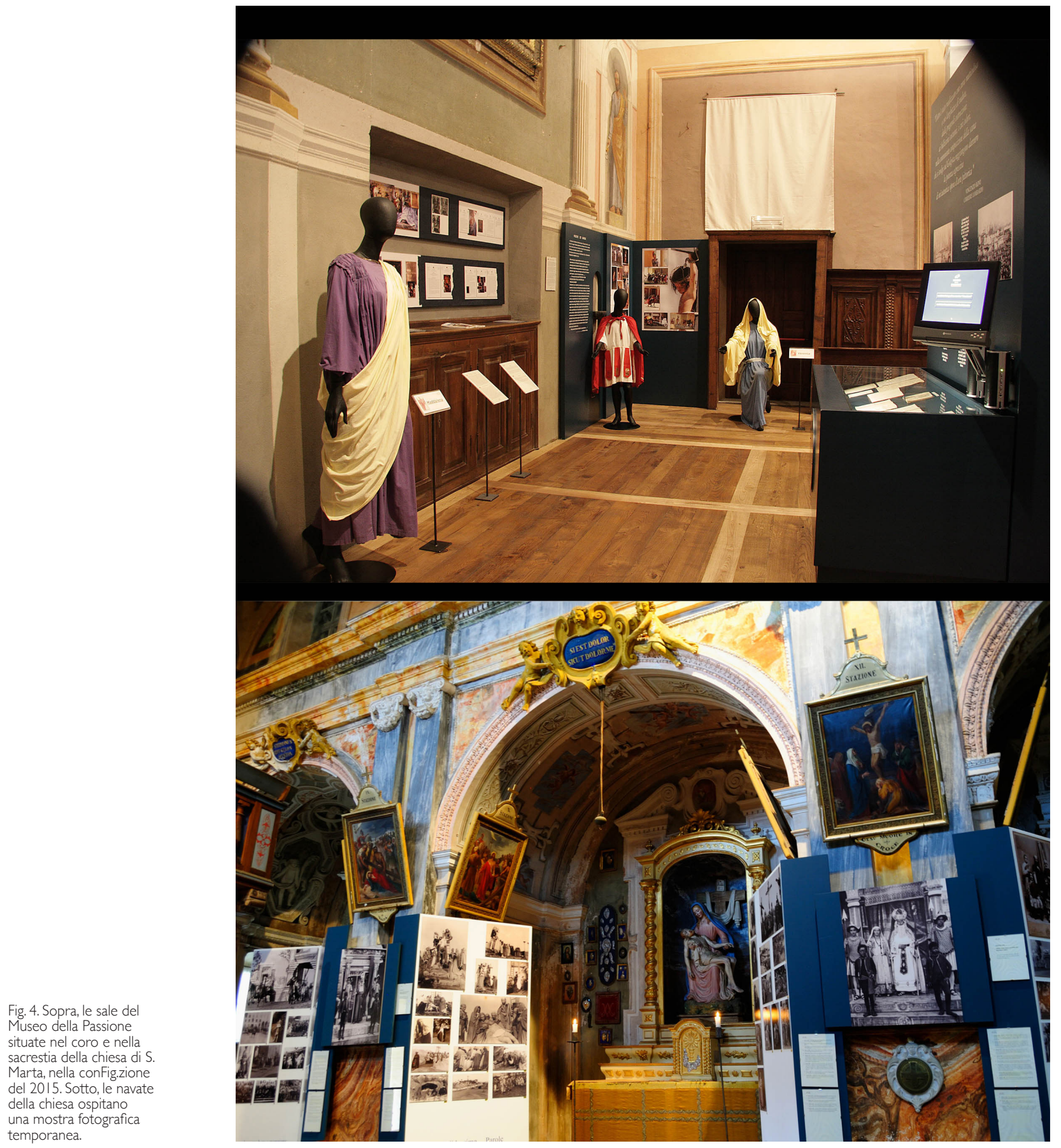


\section{Allestimento di ambienti virtuali: alcune esperienze di ricerca}

Dagli anni Ottanta del secolo scorso si stanno sviluppando interessanti ricerche nell'ambito della computer grafica per i beni culturali, attraverso esperienze di modellazione digitale ricostruttiva. Ed è in questo contesto che si afferma l'Archeologia Virtuale, disciplina umanistico-tecnica che vede nell'impiego di metodi e strumenti della rappresentazione digitali la possibilità di creare conoscenza: attraverso la documentazione e la divulgazione di contenuti scientifici, i musei sono esortati a modificare le modalità di narrazione, da "lineare e didascalica" a "informativa, persuasiva ed educativa" [Gabellone 2020, p. I25].

Numerosi progetti di ricerca interdisciplinari vedono istituzioni di stampo umanistico collaborare con professionisti e università. Tra le più interessanti si ricordano:

- Rome Reborn. Progetto internazionale, coordinato dal direttore del Virtual World Heritage Laboratory dell'Università della Virginia, il cui obiettivo consiste nella ricostruzione virtuale della città di Roma, dalla tarda età del bronzo fino all'epoca altomedievale. I primi esiti erano accessibili attraverso la piattaforma di Google Earth personalizzata per consentire una navigazione 4D.

- Nu.M.E. Progetto coordinato dall'Università di Bologna per creare un museo virtuale capace di proporre una lettura continua dell'evoluzione della città di Bologna mediante ambienti virtuali. Nella metodologia applicata si possono distinguere tre fasi: l'analisi delle fonti, la modellazione e la navigazione. Durante l'analisi delle fonti è ben descritto come le fonti iconografiche, seppur molto affascinanti -ma non sempre affidabili- sono state analizzate con estrema attenzione. Nella fase di modellazione sono stati inizialmente identificati e digitalizzati i dati geometrici acquisiti da campagne di rilievo dei periti agrimensori; in seguito sono stati analizzati gli edifici che si attestano sullo spazio pubblico. Per la navigazione sono stati utilizzati strumenti open source, a garanzia di una maggiore diffusione dei contenuti e per una salvaguardia della piattaforma da una veloce obsolescenza.

- The Monastery of Dordrecht. Progetto nato dalla collaborazione tra l'archivio della città di Cordrecht in Olanda, e la società Paladin Studios. La ricostruzione digitale fa ora parte di un allestimento museale che illustra la storia del monastero, dalla sua fondazione fino ai giorni nostri. Durante la fase di ricostruzione un team di storici, archeologi e umanistici ha collaborato con i tecnici del Paladin Studios. L'esito che ne deriva è un ambiente virtuale in cui l'utente può muoversi da una vista a $360^{\circ}$ a un'altra: non si configura pertanto come uno scenario pienamente navigabile, ma la resa grafica dei materiali e l'attenzione per i dettagli gli conferiscono un aspetto particolarmente realistico.

\section{Digital historical scenic design per il Museo della Passione}

L'Associazione Teatro Popolare di Sordevolo ha inaugurato nel 2015 il Museo della Passione, allestito nel coro e nella sacrestia della chiesa di S. Marta (fig. 4). L'allestimento proposto non si limita all'esposizione degli oggetti di scena, ma è incentrato sulla narrazione delle persone che a vario titolo hanno contribuito a dar vita a questo evento nel corso delle
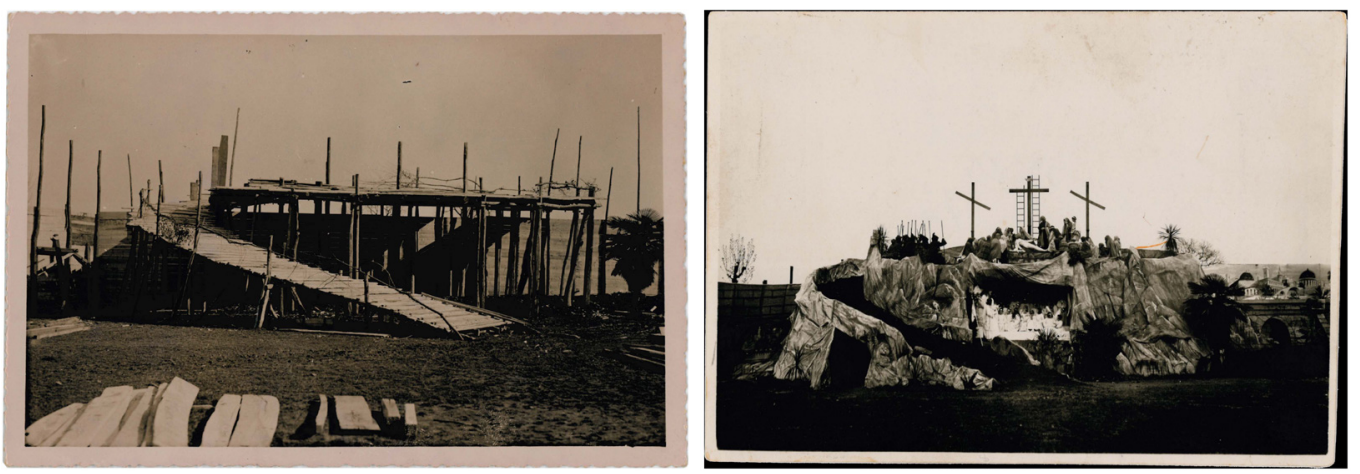
Fig. 7. Foto del Calvario durante la scena della crocifissione (1950)
Fig. 8. Confronto tra fonti iconografiche e modello ricostruito. Da sinistra: Cattedra di Anna (1934) Cattedra di Caifas (1934)

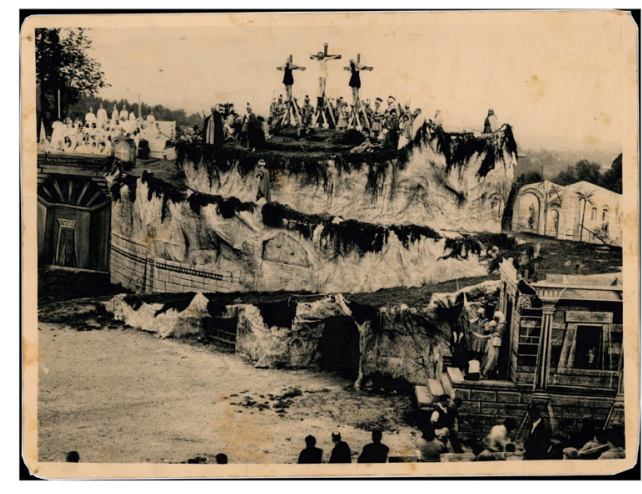

varie edizioni. II visitatore può fruire di brevi filmati, fotografie, documenti e oggetti scenici, apprezzandone sia il senso artistico sia l'animo - la Passione- che è alla base di questa sacra rappresentazione.

In occasione delle opere di ristrutturazione e rinnovamento degli allestimenti interni del museo, l'Associazione ha deciso di integrare le collezioni con nuovi contenuti digitali, esito del progetto di ricerca dal titolo Digital historical scenic design, svolto in collaborazione con il Politecnico di Torino. Nel precedente allestimento il museo, seppur estremamente ricco di beni ascrivibili alle rappresentazioni del passato, peccava in alcune parti di scarsa attrattività. Per tale ragione si è deciso di accompagnare la visita del museo con una sapiente integrazione di nuovi contenuti digitali atti alla divulgazione di contenuti rivolti a un pubblico non specializzato.

Per rievocare alcune emblematiche rappresentazioni del passato, si è deciso di partire dalla creazione di alcuni ambienti digitali, le scenografie, riviste quasi integralmente da un'edizione all'altra. Gli elementi principali quali le quattro cattedre e il calvario sono elementi che caratterizzano l'intero processo di progettazione dell'allestimento scenico, in un processo co-partecipativo che include la costruzione fisica dei diversi elementi scenici e del contesto, per dar vita a uno spettacolo 'inedito' (figg. 5-7). Proprio grazie al senso di identità che pervade la comunità sordevolese, l'intero processo di produzione teatrale è ben documentato da un ricco archivio fotografico e dalla raccolta di un esteso apparato documentale composto di schizzi, progetti scenografici, documenti assembleari, rendicontazioni economiche e alcuni video (1934).
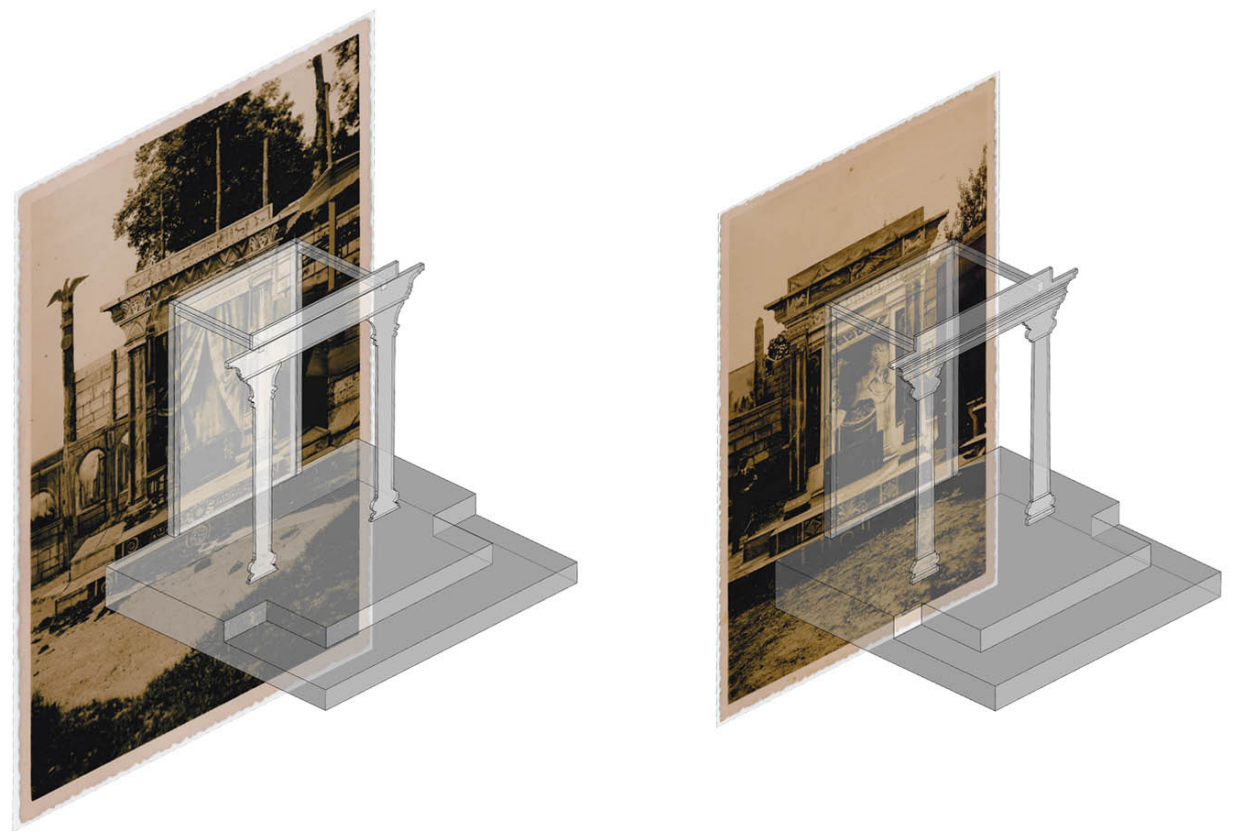
Fig. 9. Confronto tra fonti iconografiche e modello ricostruito. Da sinistra: Cattedra di Erode (1950) Cattedra di Pilato (1950).
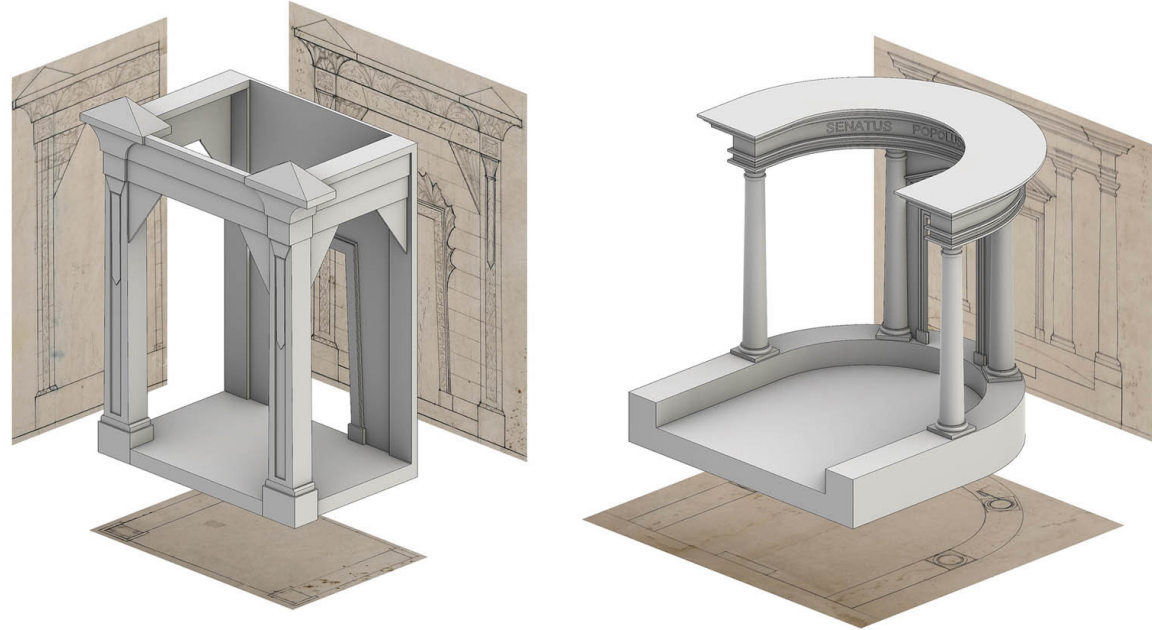

Il cospicuo materiale archivistico, messo a disposizione dal Museo della Passione, ha fornito le basi per la fase ricostruttiva. La fase preliminare è consistita nella raccolta, analisi e digitalizzazione delle fonti, a cui ha fatto seguito la fase di modellazione. Sulla base della qualità e affidabilità differente delle informazioni raccolte [Bianchini, Nicastro 20 8], sono stati predisposti differenti gruppi di oggetti:

- un primo gruppo di oggetti è costituito dagli elementi scenici maggiormente documentati, sia da disegni di progetto e relativi dettagli, sia dalle fotografie di scena e da alcune di fasi di cantiere. In questo caso l'accurata documentazione ha permesso una ricostruzione di livello qualitativamente più elevato (figg. 8- I0);

- un secondo gruppo di elementi si riferisce ad altri componenti architettonici quali spalti o tribune: tali elementi, non sono riportati nei disegni di progetto; seppur presenti in numerose immagini, non sono ben visibili (per via delle persone sedute), si hanno alcune bozze relative alle proporzioni e alla loro collocazione, oltre a qualche fotografia di cantiere;

- al terzo gruppo di oggetti fanno riferimento quegli elementi di scena di dimensioni e complessità minore, non documentati in modo esaustivo, tra cui alcuni complementi d'arredo che non richiedevano disegni di dettaglio per la loro realizzazione e venivano prestati dalle famiglie sordevolesi.

Si è optato per una resa di tipo concettuale, anche tematizzata, evitando di perseguire una resa iper-realistica non congruente con gli altri materiali esposti. II modello è stato creato con software e modalità di modellazione poligonale che permettessero una facile implementazione nelle fasi successive (fig. I I).

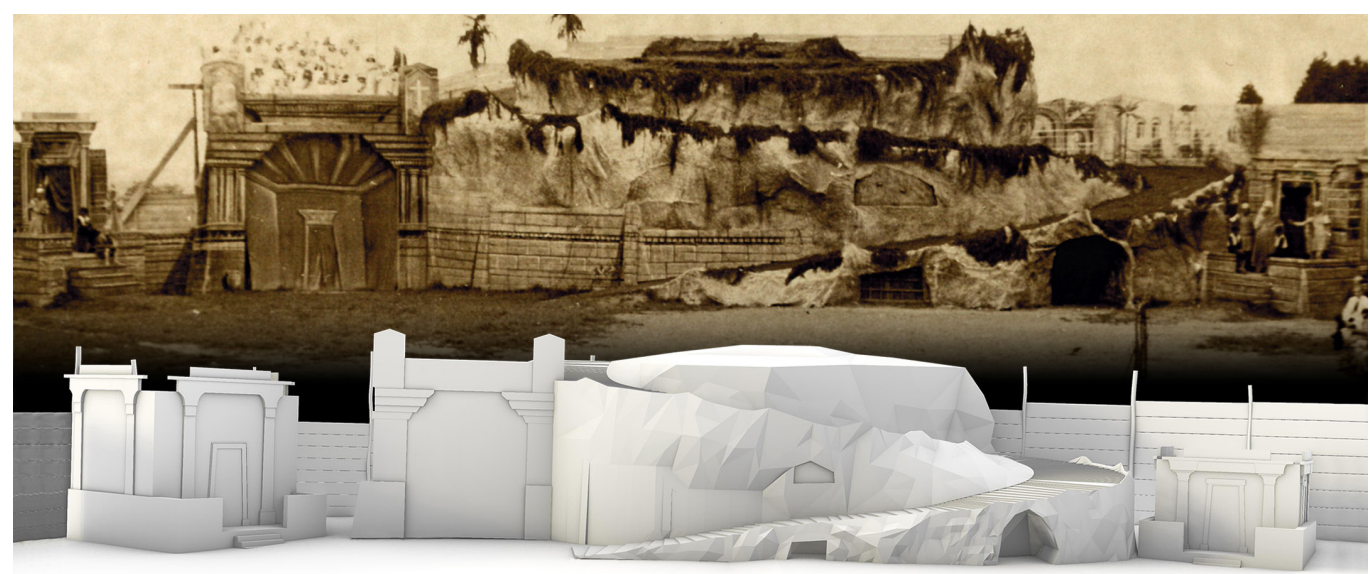

Fig. 10. Confronto tra ricostruzion cotorica e ricostruzione concet
(1950). Da sinistra:

Cattedra di Anna, Portone di ingresso per i cavalli e gradonata degli angeli, Calvario, Cattedra di Caifas. 
Successivamente si è definito uno storyboard dei due video richiesti, per organizzare efficacemente una narrazione che prevedesse transizioni dal modello virtuale alle immagini d'epoca. Per una corretta percezione dello spazio e del rapporto tra elementi di scena e pubblico le ricostruzioni vengono inizialmente visualizzate a volo d'uccello; successivamente, la camera si muove ad altezza uomo all'interno del perimetro scenico soffermandosi sulle inquadrature più significative e connotanti i due differenti spettacoli teatrali. Gli elementi caratterizzanti sono stati identificati dall'analisi delle fonti di archivio (Orsi 2000) come lo scritto del Pinotto [2], noto studioso sordevolese che nel 1934 ha seguito più volte lo spettacolo e ne ha appuntato critiche positive e negative, oggetto di successive valutazioni per gli allestimenti delle successive edizioni.

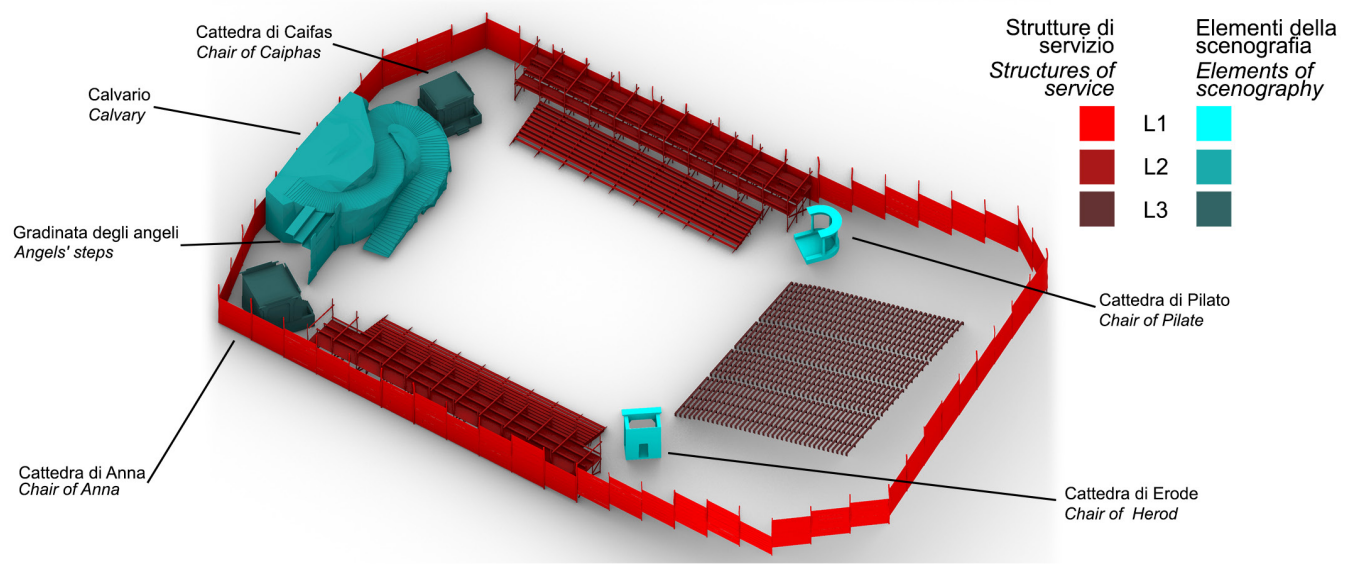

\section{Conclusioni}

Gli esiti descritti rappresentano un primo importante esito dell'attività di ricerca avviata tra il Politecnico di Torino e il Museo della Passione di Sordevolo. Future attività prevederanno la digitalizzazione delle fonti archivistiche e la messa a sistema di un'organizzazione semantica dei contenuti strutturati secondo diversi livelli di conoscenza e resi fruibili anche in modalità remota.

Proprio le nuove tecnologie possono essere utili non solo alla revisione degli allestimenti museali, ma anche alla indispensabile revisione dei racconti connessi alle collezioni museali al fine di soddisfare dell'aspettativa di evoluzione del racconto che finora è quasi sempre negata [Orsini, Lampis 2019]. Secondo Luigini, "quando l'output di un'attività è la produzione di un'opera tangibile, questo porta con sé una serie di connessioni visibili e invisibili con altri elementi dell'esperienza che costituiscono l'effettivo valore aggiunto di quel prodotto. È proprio questo processo che permette alle opere, ai beni culturali di trasmettere informazioni, conoscenze, emozioni, trasformandosi nel tempo e risemantizzandosi." [Luigini, Panciroli 2018, p. 23].

Lo stesso Lampis sottolinea la necessità di un avveduto rigore nella loro applicazione per non incorrere nel rischio di una semplificazione che possa sconfinare nella banalizzazione. Occorre quindi una mano (e una mente) in grado di districarsi tra le innumerevoli modalità offerte dalla moderna technè, orientandone le scelte nella progettazione di nuove forme di fruizione culturale (fig. 12). A questo riguardo, in occasione dell'inaugurazione della mostra temporanea Archeologia Invisibile (2019) presso il Museo Egizio, il direttore rifletteva sul ruolo del museo: "I mutamenti continueranno. Si penseranno diverse soluzioni organizzative e architettoniche che possano rispondere alle esigenze contemporanee. Ci saranno certamente anche nuove forme di fruizione culturale. Il compito sarà sempre quello di migliorare l'esperienza visiva, estetica e intellettuale del visitatore, cercando di fornire le informazioni necessarie per arricchirne la comprensione. II futuro quindi dei musei è, come è sempre stato, la ricerca" [Greco 20 I9, p. 20]. E non possiamo che essere d'accordo. 
Fig. 12. Lo spettacolo della Passione recitato
dai bambini (Archivio Passione 2010). Credits: Foto Perini Biella.

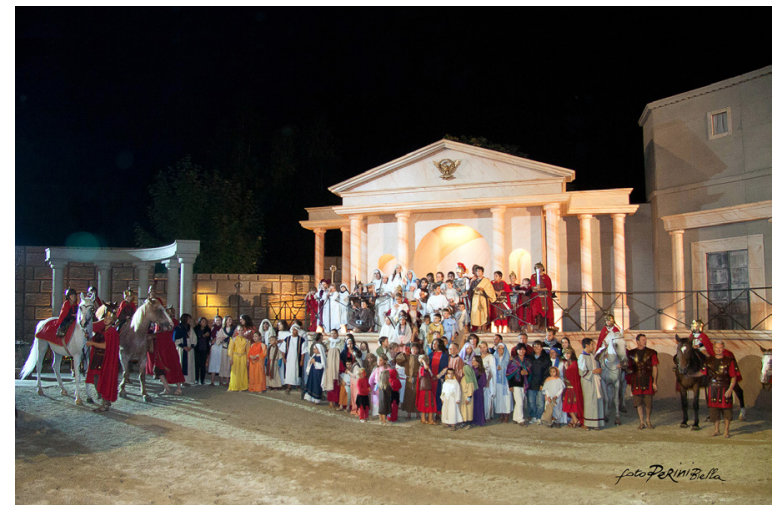

Note

[I] UNESCO, Executive Board. Decisions adopted by the Executive Board at its 154th Session (Paris, 27 April-7 May 1998), 3.5 Culture 3.5.I Proposal by the Director-General concerning the criteria for the selection of spaces or forms of popular and traditional cultural expression that deserve to be proclaimed by UNESCO to be masterpieces of the oral heritage of humanity (I54 EX/13 and I54 EX/52) pp. I4, I5 ttp://unesdoc.unesco.org/images/00 I 1/00 I I 20/I I 20 I 9e.pdf (consultato il 20 marco 2021).

[2] Pinotto (1934). A Ricordo della Passione di N.S.G.C. rappresentata in Sordevolo nell'anno MCMXXXIV (XII E.F.).

\section{Riferimenti bibliografici}

Associazione Teatro Popolare di Sordevolo (20 I5). La Passione di Sordevolo. Immagini e parole. Gaglianico (BI): Botalla Editore.

Alivizatou M. (2007). The UNESCO programme for the Proclamation of Masterpieces of the Oral and Intangible Heritage of Humanity: A critical examination. In Journal of Museum Ethnography. n. 19, pp. 34-42.

Bianchini C., Nicastro S. (20।8). La definizione del Level of Reliability: un contributo alla trasparenza dei processi di Historic-BIM. In Dn - Building Information Modeling, Data \& Semantics. n. 2, pp. 45-59.

Bonacini E. (2020). I musei e le forme dello storytelling digitale. Roma: Aracne.

Bortolotto C. (2007). From Objects to Processes: UNESCO'S' Intangible Cultural Heritage'. In Journal of Museum Ethnography. n. 19, pp. 21-33.

Gabellone F. (2020). Archeologia virtuale. Teoria, tecniche e casi di studio. Lecce: Edizioni Grifo.

Greco C. (2019). La biografia degli oggetti. Rivoluzione digitale e Umanesimo. In Ciccopiedi C. (a cura di). Archeologia invisibile. Catalogo della mostra. Modena: Franco Cosimo Panini Editore.

Gütermann C. F. (2019). Sordevolo. Dove la Passione opera. Gaglianico (BI): Botalla Editore.

Luigini A., Panciroli C. (20।8). Ambienti digitali per l'educazione all'arte e al patrimonio. In Luigini A., Panciroli C. (a cura di) (20 I8). Ambienti digitali per l'educazione all'arte e al patrimonio. Milano: Franco Angeli, pp. I7-32.

Orsi D. (2000). La Passione di Sordevolo. Studio di drammatica popolare. Torino: Omega Edizioni.

Orsini A., Lampis A. (2019). Piano Triennale per la Digitalizzazione e l'Innovazione dei Musei. Mibac, Direzione Generale Musei. <http://musei.beniculturali.it/wp-content/uploads/20 I 9/08/Piano-Triennale-per-la-Digitalizzazione-e-l'Innovazione-dei-Musei. pdf> (consultato il 9 febbraio 2021).

UNESCO (1989). Recommendation on the Safeguarding of Traditional Culture and Folklore: <http://portal.unesco.org/en/ev.phpURL_ID=|3|4|\&URL_DO=DO_TOPIC\&URL_SECTION=20 I.html> (consultato il 9 febbraio 202 I).

UNESCO Masterpieces of the Oral and Intangible Heritage of Humanity: Proclamations 2001, 2003 and 2005: <https://unesdoc. unesco.org/ark:/48223/pf0000 I $47344>$ (consultato il 9 febbraio 2021).

Viola F., Cassone V. I. (2017). L'arte del coinvolgimento: emozioni e stimoli per cambiare il mondo. Milano: Hoepli Editore.

\section{Autori}

Massimiliano Lo Turco, Politecnico di Torino, massimiliano.loturco@polito.it

Elisabetta Caterina Giovannini, Politecnico di Torino, elisabettacaterina.giovannini@polito.it Andrea Tomalini, Politecnico di Torino, andrea.tomalini@polit.it

Per citare questo capitolo: Lo Turco Massimiliano, Giovannini Elisabetta Caterina,Tomalini Andrea (202I). Valorizzazione del patrimonio immateriale attraverso le tecnologie digitali: la Passione di Sordevolo/Enhancing intangible heritage trough digital technologies: La Passione di Sordevolo. In Arena A., Arena M., Mediati D., Raffa P. (a cura di). Connettere. Un disegno per annodare e tessere. Linguaggi Distanze Tecnologie. Atti del $42^{\circ}$ Convegno Internazionale dei Docenti delle Discipline della Rappresentazione/Connecting. Drawing for weaving relationship. Languages Distances Technologies. Proceedings of the $42^{\text {th }}$ International Conference of Representation Disciplines Teachers. Milano: FrancoAngeli, pp. $1689-1708$. 


\title{
Enhancing Intangible Heritage trough Digital Technologies: La Passione di Sordevolo
}

\author{
Massimiliano Lo Turco \\ Elisabetta Caterina Giovannini \\ Andrea Tomalini
}

Abstract

UNESCO member states define intangible cultural heritage $(\mathrm{ICH})$ as the set of practices, representations, expressions, as well as knowledge and skills that communities, groups and, in some cases, individuals recognize as an integral part of their cultural heritage.

The Museo della Passione of Sordevolo protects, preserves and spreads the cultural and social value of the largest popular Christian representation in Italy, called La Passione di Sordevolo, which every five years since 1816 evokes the Passion of Christ, involving most of the inhabitants of Sordevolo and its surroundings.

The contribution presents some results of the research of the reconstructive modelling and visual storytelling project called 'Digital historical scenic design'. The project explores the use of digital technologies for the creation of new languages of expression and creative production, through the processing of documentary heritage (photographs, sketches, drawings) and the systematic collection of oral tradition handed down from generation to generation to the members of the local community. The use of different narrative strategies enables to virtually recreate part of the experience of the Passion staged in 1934 and 1950. This form of popular theatre deserves to be protected and disseminated through digital media, especially in this particular period in which any activity in presence is interrupted due to the ongoing pandemic situation.

Keywords

Reconstructive digital modelling, storytelling, popular theatre, intangible cultural heritage.

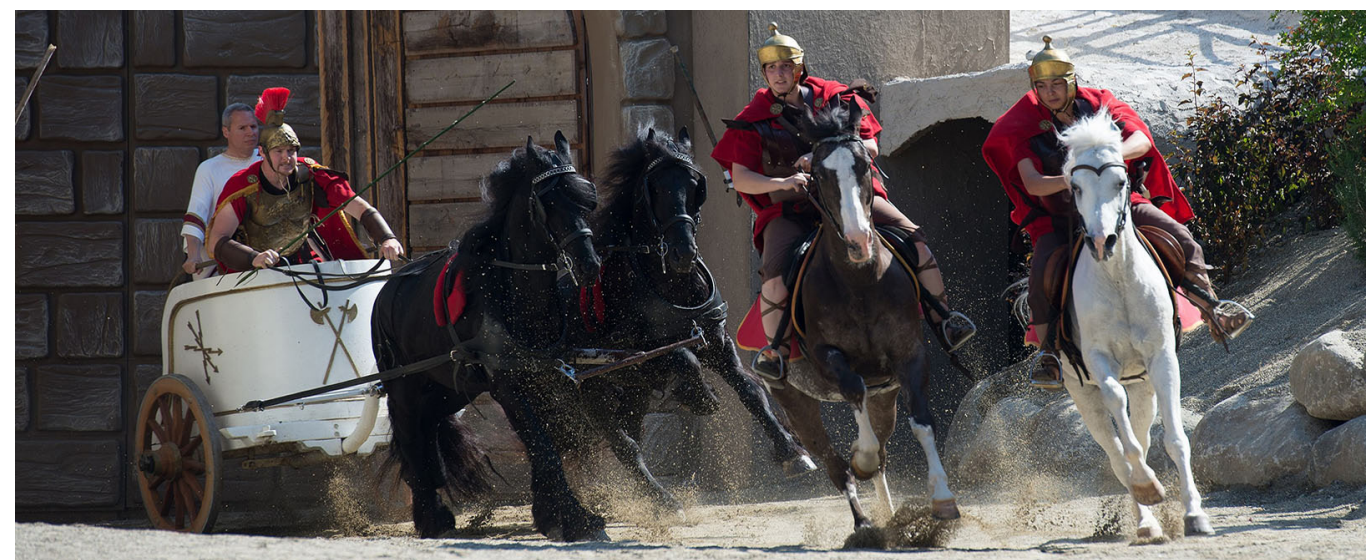




\section{Introduction}

The term intangible cultural heritage is the result of multiple initiatives that have shaped its meaning with a definition that considers this heritage no longer as a mere cultural expression but rather as a process where cultural identity, tradition and knowledge coexist and persist thanks to their communities.

Since 1952, the term 'folklore' has been used to indicate this type of cultural heritage. It was defined in 1989 as traditional and popular culture recognized as meeting the expectations of the community as an expression of its cultural and social identity, norms and values that are transmitted orally, Following the Recommendation for the Safeguarding of Culture and Folklore (1989), it is considered of primary importance the safeguarding of this heritage that, with the General Conference of UNESCO in Paris (1998) is called Intangible Heritage and that will be followed by the Proclamation of the Masterpieces of the Oral and Intangible Heritage of Humanity [Alivizatou 2007]. This initiative aimed to identify permanent spaces and forms of popular and traditional cultural expression that deserved to be proclaimed symbols of oral heritage, as they constituted "exceptional examples of freedom and diversity of cultural expression, of social interaction, tolerance and cultural understanding, of the preservation of the collective memory, of the education of youth, of the oral transmission of universal values, of exchanges among generations and of urban integration" [I].

Various forms of cultural expression and cultural spaces belonging to seventy different countries received recognition following three different proclamations (200I, 2003 and 2005): for the first time, local communities were invested with the role of keepers of tradition with the task of safeguarding their intangible heritage, promoting their active involvement in the transmission of their traditions to future generations.

Since 2003, with the Convention for the Safeguarding of Intangible Cultural Heritage, five domains have been identified through which intangible cultural heritage, as follows:

I. Oral traditions and expressions, including language as a vehicle for intangible cultural heritage.

2. Performing arts.

3. Social practices, rituals, and celebratory events.

4. Knowledge and practices concerning nature and the universe.

5. Traditional crafts.

The representation of the Passione di Sordevolo is fully eligible for some of these domains: the intangible heritage to be preserved is not the single cultural event itself, but also the

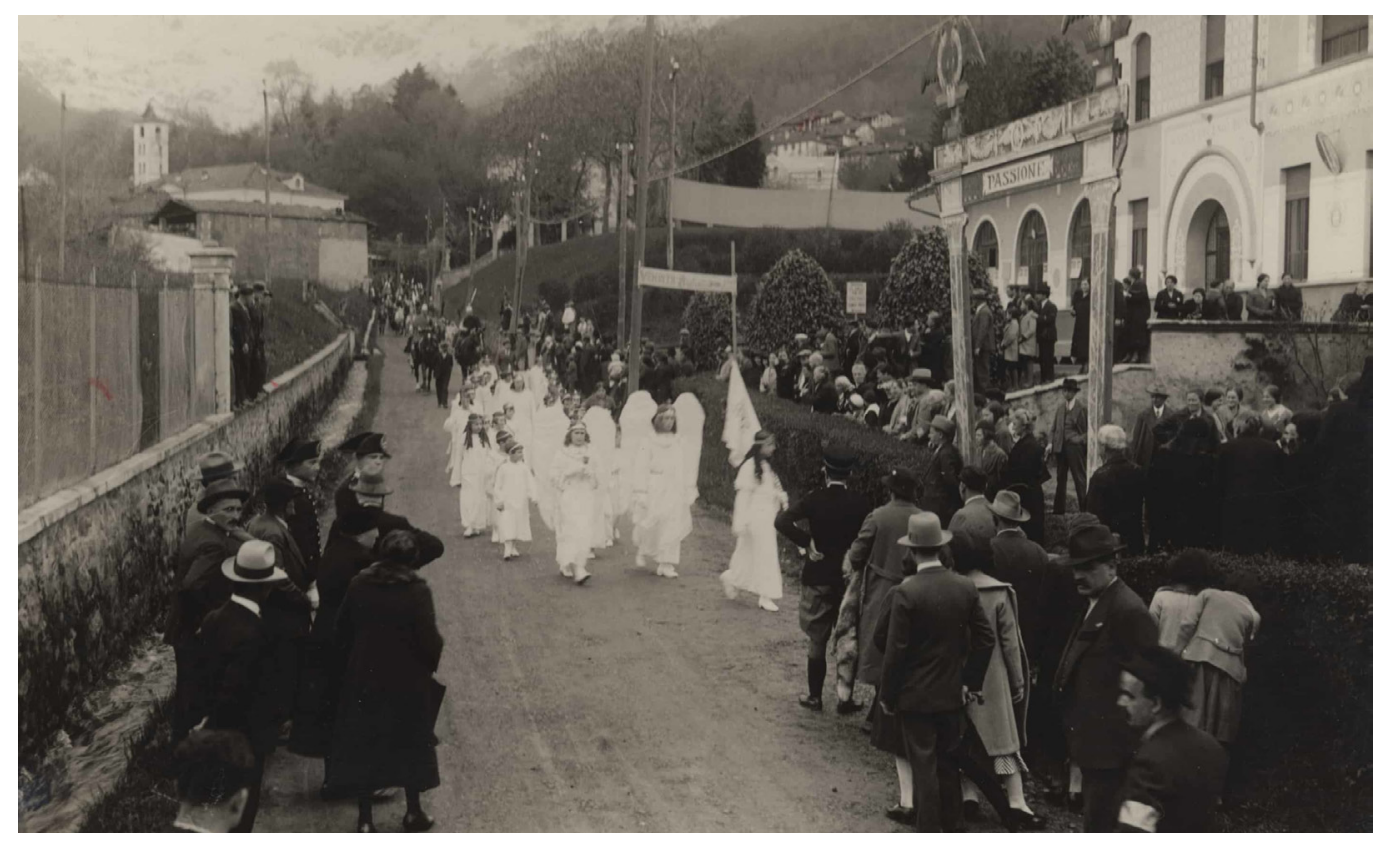


knowledge that is transferred from generation to generation and passed on through the centuries by the community of Sordevolo. A cultural value that today is recognized by the local community as an integral part of its own cultural heritage. This intangible heritage needs the protection of the processes of artistic production of the show itself so that it can shape the community's memory [Bortolotto 2007]. Communicating this kind of heritage means going beyond the normal museographic strategies that tend to transform intangible heritage into a tangible form in order to preserve, archive and communicate it.

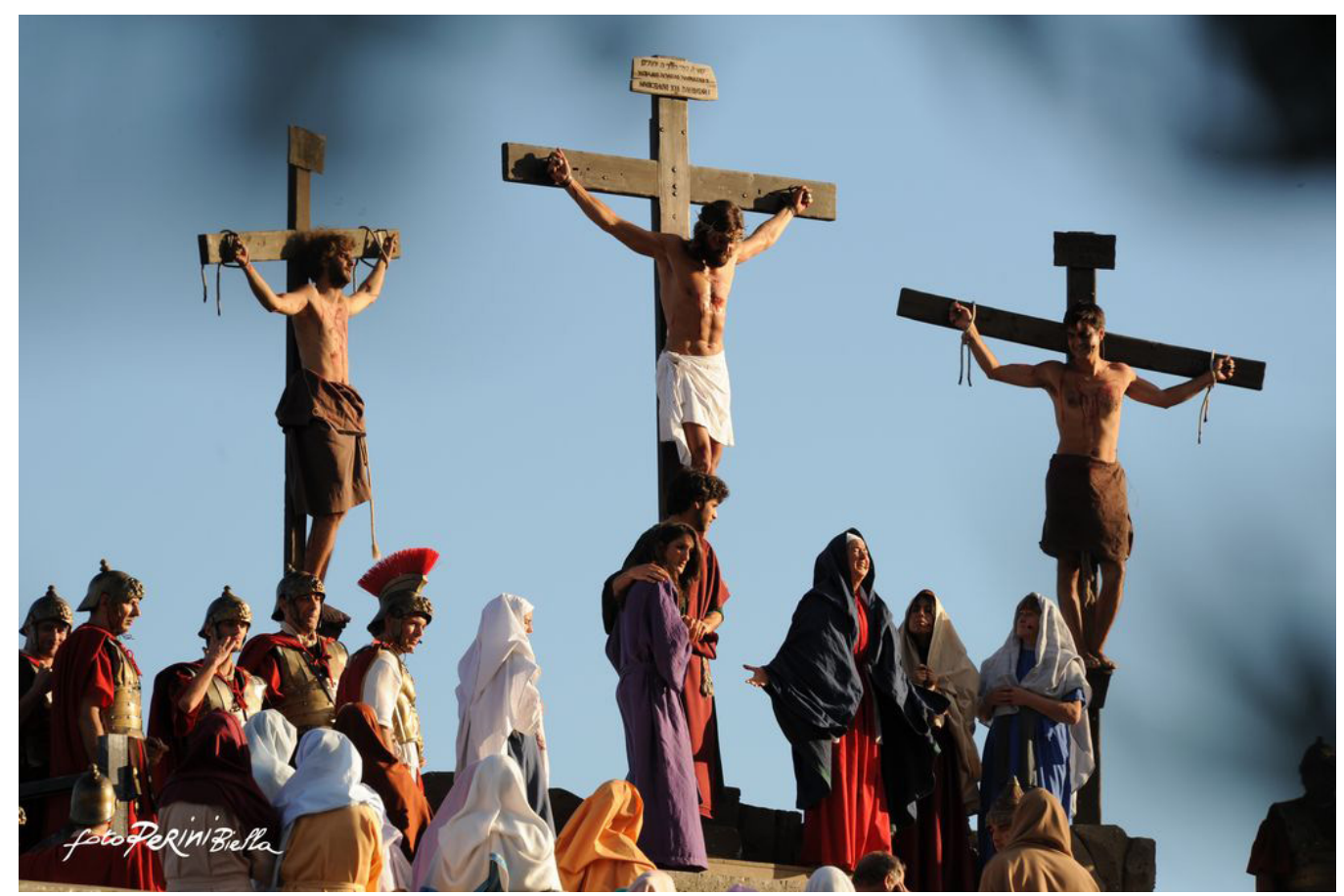

\section{Digital Storytelling}

With the advent of digital technologies, the internet and social media, museums are faced daily with new challenges to preserve and promote cultural heritage using new languages and new narratives. On the one hand, major museums are among the institutions that have invested the most in multi-channel and multi-platform communication, highlighting how museum curators themselves are becoming excellent communicators [Bonacini 2020]. On the other hand, small institutions struggle to structure effective communication strategies. The COVID- 19 has also highlighted how the digital transformation of the cultural sector is more necessary than ever to recognize our heritage as an essential service for citizens, as the health and the education, as desired by the Decreto Colosseo n. 146/20I 5.

In the volume I musei e le forme dello storytelling digitale Bonacini critically examines various types of digital storytelling to date that can be traced back to the field of cultural heritage. The essay is mainly based on the division into three types of involvement: experience, interaction, attraction [Viola 2017].

At this regard, the experiences described show that the process of democratization of culture is still incomplete and propose new forms of fruition in which digital technologies can reduce the digital divide between the scientific world and the community. The same approach can be applied to the field of research communication and to the use of public engagement tools for academic communities and public or private research institutions. It is more appropriate than ever to consider the real benefits of this democratization of culture where the user becomes a co-creator of knowledge and new digital content: on the one 
side it emerges the need, not only socio-cultural but also economic, to find new narratives to convey cultural content, on the other one, the risk is an intellectual levelling of research practices that underlie the creation of these contents.

Moreover, the ambiguity between the creation of content for dissemination purposes and the creation of content useful to enhance and authoritatively accredit the results achieved for the various interested users becomes evident.

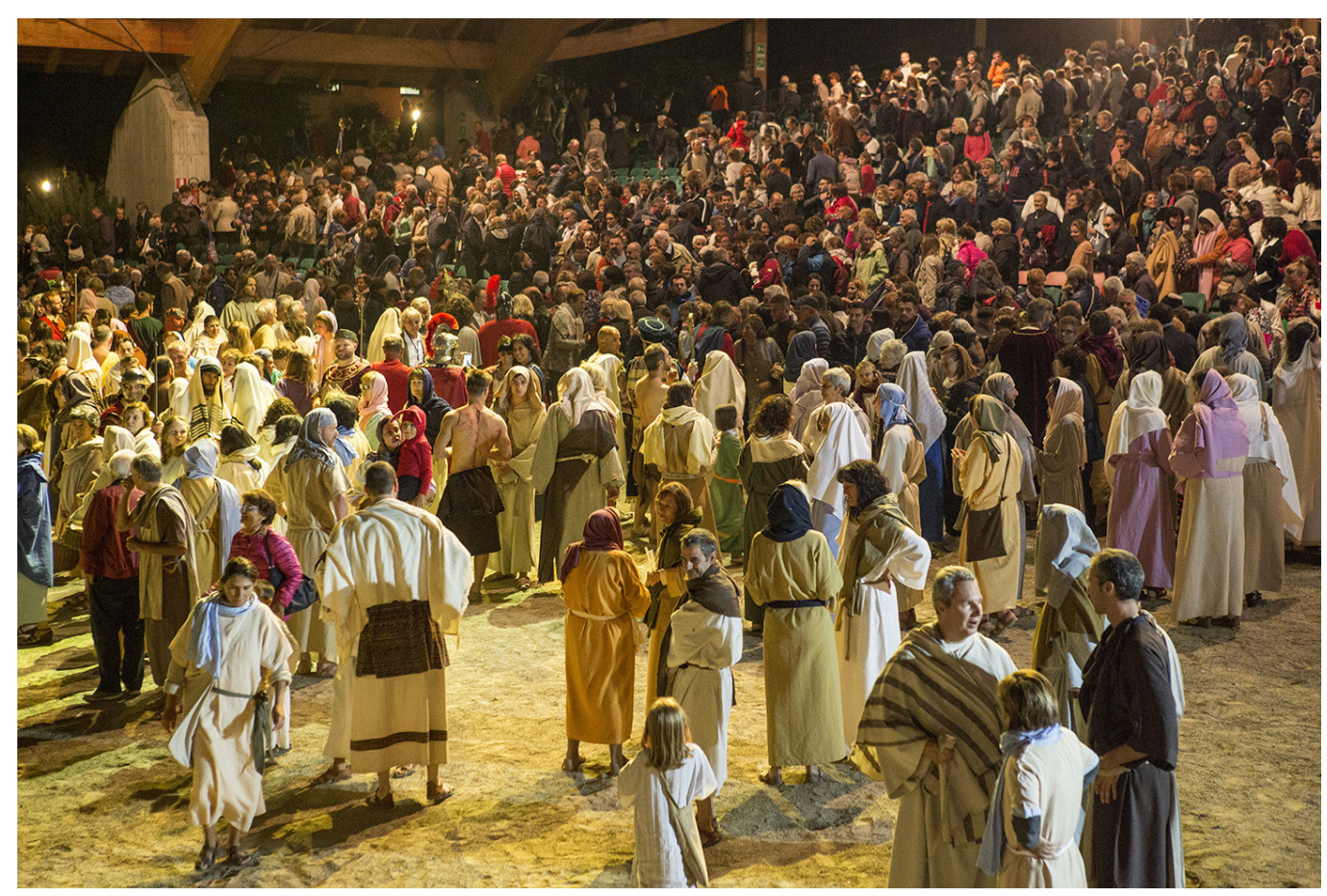

\section{The case study: la Passione di Sordevolo}

Located in the Elvo valley, a natural land at the foot of the Alps, the Piedmontese town of Sordevolo can be considered a place of faith and popular devotion, whose most emblematic expressions are the seven churches and the representation of the Passion with its two centuries of history. In 1815 the villagers made a promise to perform the play every 5 years if they were saved from the plague that was devastating the village. Since that date, the text used is the version produced in 1500 by Giuliano Dati, a chaplain of the church of Santi Martiri in Trastevere, in Rome. He wrote the lines of the work in a form of archaic Italian called Laudi used for the Via Crucis staged every Holy Friday at the Colosseum, also known as the Devotizione del Colosseuo. That performance was notable for its large turnout of pilgrims, travellers and celebrities, but in I 539 it was banned by Pope Paul III because of the dramatic period of the Reformation and the subsequent breakaway of Luther, Calvin and other religious movements from the Roman Catholic Church.

The first performances of the Passione were held in different places in the town of Sordevolo (fig. I) but today the representation is staged in an open space of about 4,000 square meters where a reconstructed corner of Jerusalem, dating back to 33 A.D., is set up. The set includes Herod's Palace, the Sanhedrin, Pontius Pilate's Praetorium, the Garden of Olives, the Cenaculum and the Calvary. The scenography, entirely realized with the means and the abilities of the citizens, is prepared in the smallest details, with appropriate music and exceptional choreographies and of rare beauty (fig. 2) 
The performance lasts three hours; it consists of a prologue and 29 scenes. The performance involves the entire community over a period of about two years: about 400 locals participate in the performance, while another 300 collaborate in various capacities behind the scenes, making the costumes, designing and building the set. Many specific roles -played by ordinary citizens, not professional actors- are passed down from generation to generation (Gütermann 2019). The event is not reduced to a single event but is re-enacted for an entire summer, with approximately 40 performances spread over a period of about three months. It is a tradition that goes beyond the theatrical moment to become a cultural, social and economic event that integrates the whole community: for these characteristics the Passione di Sordevolo has to be considered as a unicum in the panorama of Italian folklore (fig. 3).
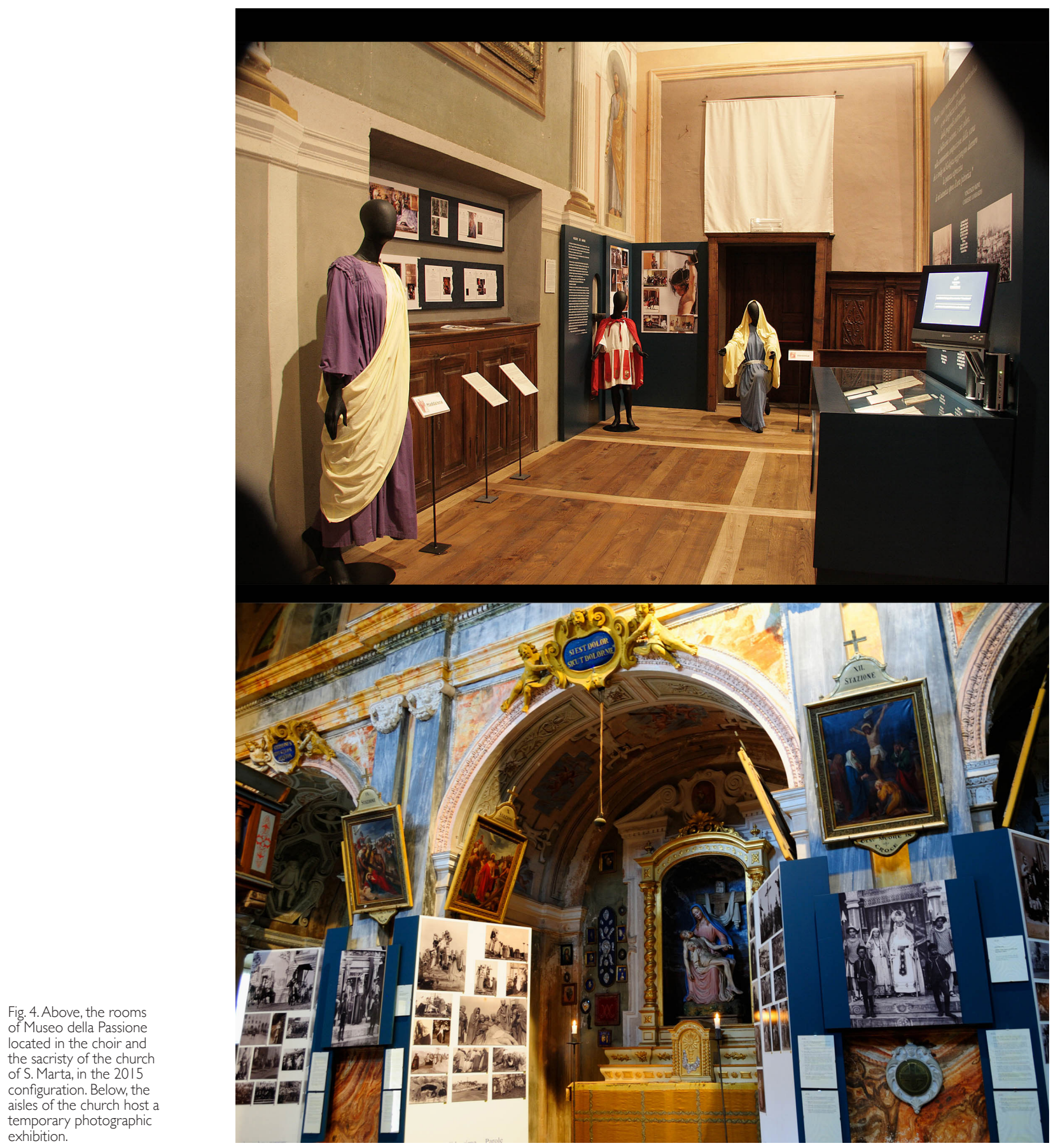


\section{The setting up virtual environments: some research experiences}

Since the eighties of the last century, interesting research has been developed in the field of computer graphics for cultural heritage, through experiences of reconstructive digital modelling. And it is the field in which Virtual Archaeology, a humanistic-technical discipline that considers the use of methods and tools of digital representation as an opportunity to create knowledge, is taking hold: through the documentation and dissemination of scientific content, museums are urged to change the mode of narration, from 'linear and didactic' to "informative, persuasive and educational" [Gabellone 2020, p. I25].

Numerous interdisciplinary research projects see humanistic institutions collaborating with professionals and universities. Some of the most interesting include:

- Rome Reborn. An international project, coordinated by the director of the Virtual World Heritage Laboratory at the University of Virginia, whose objective is the virtual reconstruction of the city of Rome, from the late Bronze Age to the early Middle Ages. The first results were accessible through the Google Earth platform properly customized to allow 4D navigation.

- Nu.M.E.. Project coordinated by the University of Bologna to create a virtual museum capable of proposing a continuous reading of the evolution of the city of Bologna through virtual environments. In the applied methodology we can distinguish three phases: the analysis of the sources, the modelling and the navigation. During the analysis of the sources it is well described how the iconographic sources, although very fascinating -but not always reliable- have been analysed with extreme care. In the modelling phase, geometric data acquired from survey campaigns of land surveyors were initially identified and digitized; then the buildings standing on the public space were analyzed. Open source tools were used for the navigation, as to guarantee a greater diffusion of the contents and to safeguard the platform from a fast obsolescence.

- The Monastery of Dordrecht. This project was born from the collaboration between the archives of the city of Cordrecht in the Netherlands and the company Paladin Studios. The digital reconstruction is now part of a museum exhibit that illustrates the history of the monastery, from its foundation to the present day. During the reconstruction phase, a team of historians, archaeologists and humanists collaborated with Paladin Studios technicians. The result is a virtual environment in which the user can move from one $360^{\circ}$ view to another: it is therefore not a fully navigable scenario, but the graphic rendering of the materials and the attention to detail give it a particularly realistic appearance.

\section{Digital historical scenic design for the Museo della Passione}

In20 I 5 The Associazione Teatro Popolare di Sordevolo inaugurated the Museo della Passione, set up in the choir and sacristy of the church of S. Marta (fig. 4). The proposed layout is not limited to the display of scenic objects, but focuses on the narration of the people who in various ways have contributed to give life to this event during the various editions. The vis-
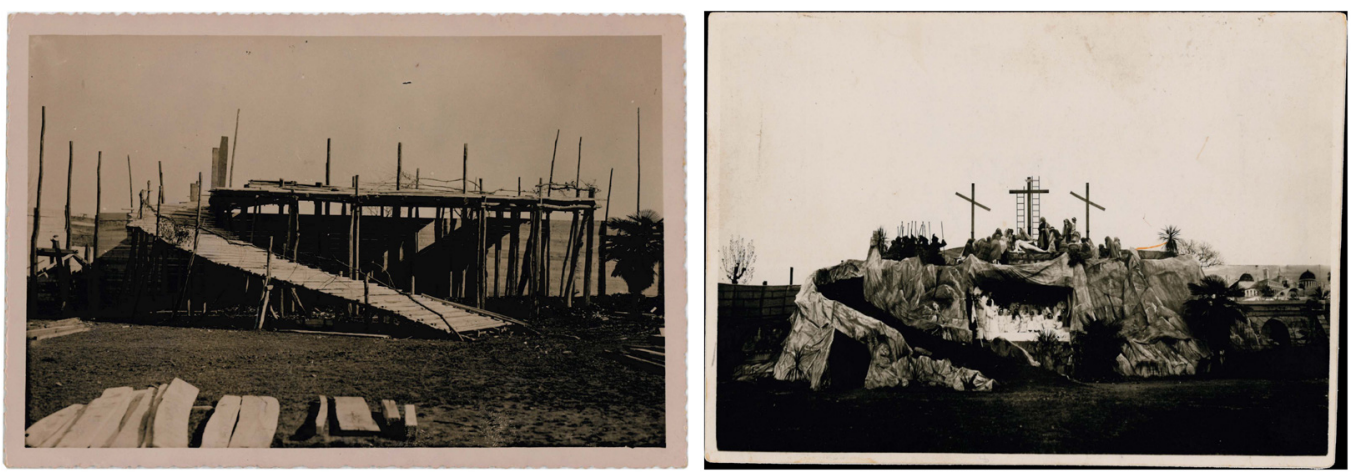


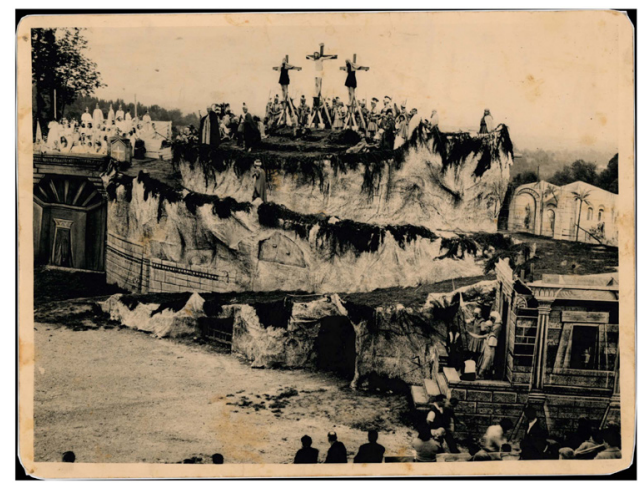

itor can also enjoy short films, photographs, documents, etc., appreciating both the artistic sense and the soul -the Passion- that is at the base of this sacred representation.

During the restoration of the museum's interior, the Associazione decided to integrate the collections with new digital content, the result of a research project entitled Digital historical scenic design, carried out in collaboration with the Politecnico di Torino. In the previous layout, the museum, although extremely rich in assets attributable to the performances of the past, lacked attractiveness in some parts. For this reason, it was decided to accompany the visit to the museum with a wise integration of new digital content aimed at the dissemination of content for a non-specialized public.

In order to evoke some emblematic representations of the past, it was decided to start from the creation of some digital environments, the sets, which were almost entirely revised from one edition to the next. The main elements such as the four cathedrals and the Calvary are elements that characterize the whole process of designing the stage set, in a co-participative process that includes the physical construction of the different scenic elements and of the context, in order to give life to an "unprecedented" performance (figs. 5-7). Thanks to the sense of identity that pervaded the local community, the whole process of theatrical production is well documented by a rich photographic archive and by the collection of an extensive documentary apparatus composed of sketches, scenographic projects, assembly documents, financial reports and some videos (1934).

The large amount of archival material made available by the museum provided the basis for the reconstruction phase. The preliminary phase consisted of the collection, analysis
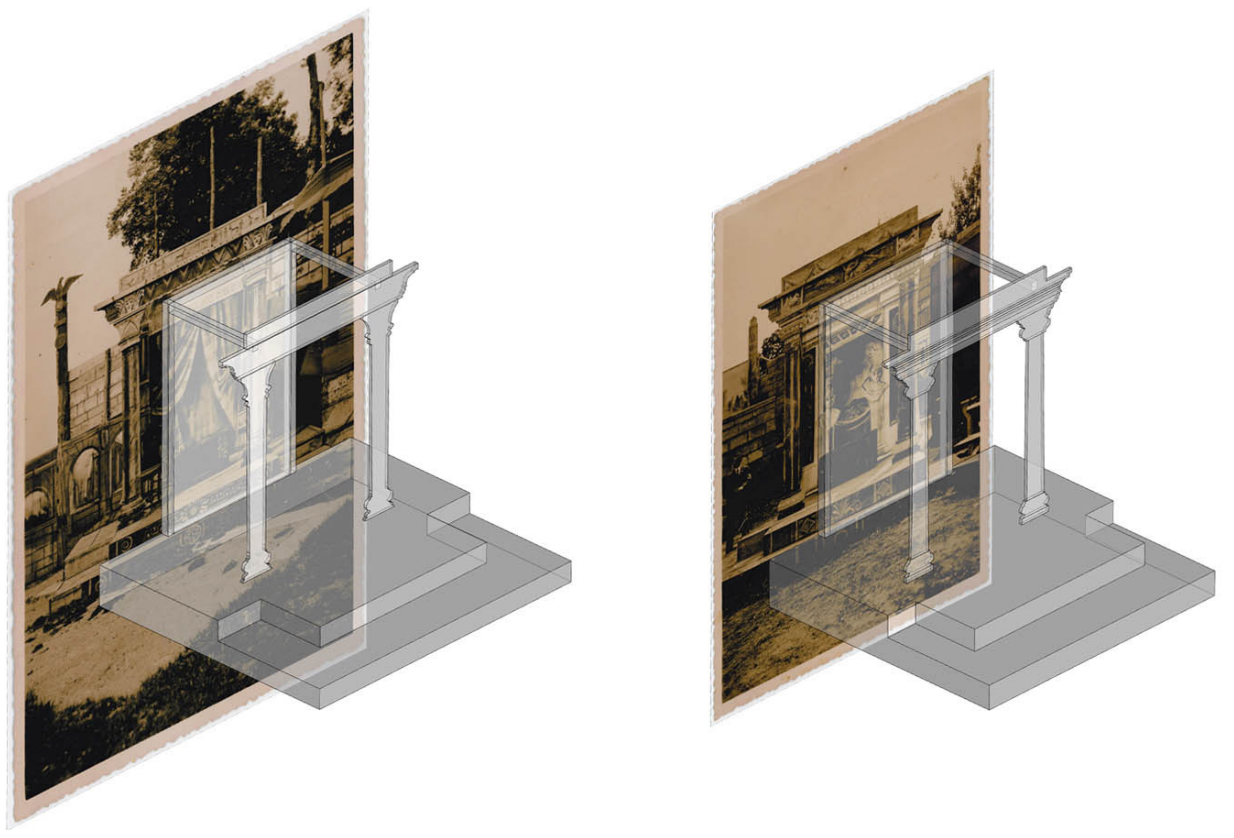
Fig. 9. Comparison between iconographic sources and

reconstructed model. From the left: Chair of Herod (1950). Chair of Pilate (1950).
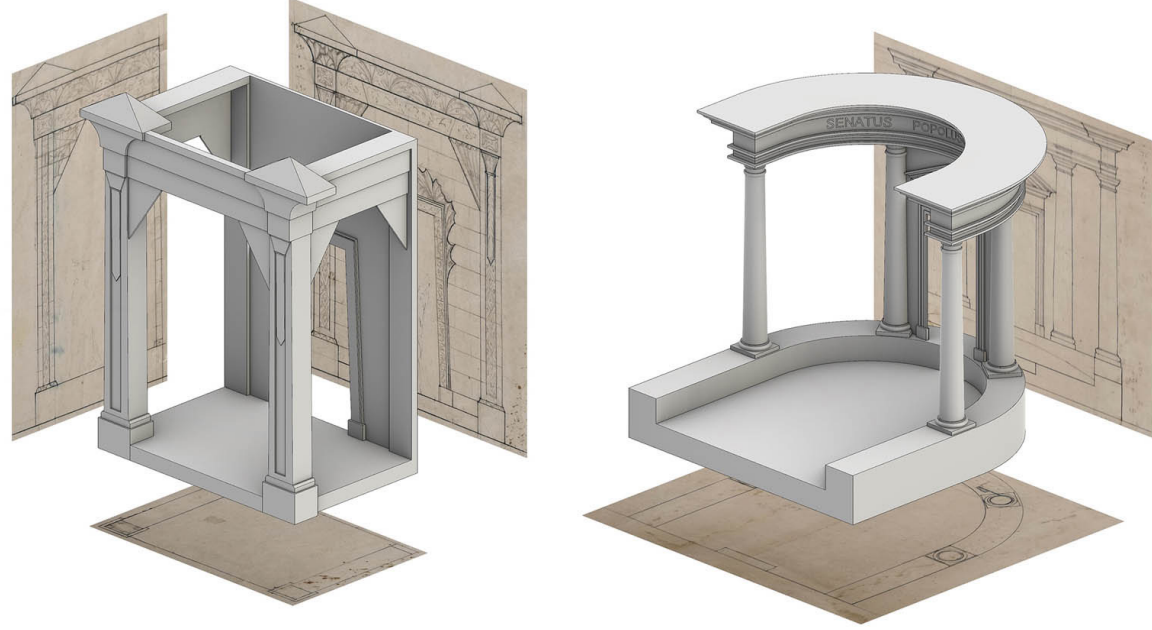

and digitization of the sources, which was followed by the modelling phase. Based on the different quality and reliability of the information collected [Bianchini 20।8], different groups of objects were prepared:

- a first group of objects is constituted by the most documented scenic elements, both from project drawings and related details, and from scene photographs and some of the construction site phases. In this case, the accurate documentation allowed a reconstruction of higher quality (figg.8- I0).

- a second group of elements refers to other architectural components such as bleachers or grandstands: these elements are not reported in the project drawings; although available in many pictures, they are not clearly visible (because of the people sitting); we have used some sketches related to the proportions and their location, as well as some photographs of the site;

- to the third group of objects refer to those elements of scene of minor dimensions and complexity, not documented in an exhaustive way, among which some furnishing accessories that did not require detailed drawings for their realization and were given by local people. A conceptual rendering style has been opted (together with thematic views), avoiding to pursue a hyper-realistic rendering not congruent with the other exposed materials. The model has been created with polygonal modelling software that would allow an easy implementation in the following phases (fig. I I).

Then, a storyboard of the two required videos was then defined to effectively organize a storytelling that included transitions from the virtual model to the historical images. For a

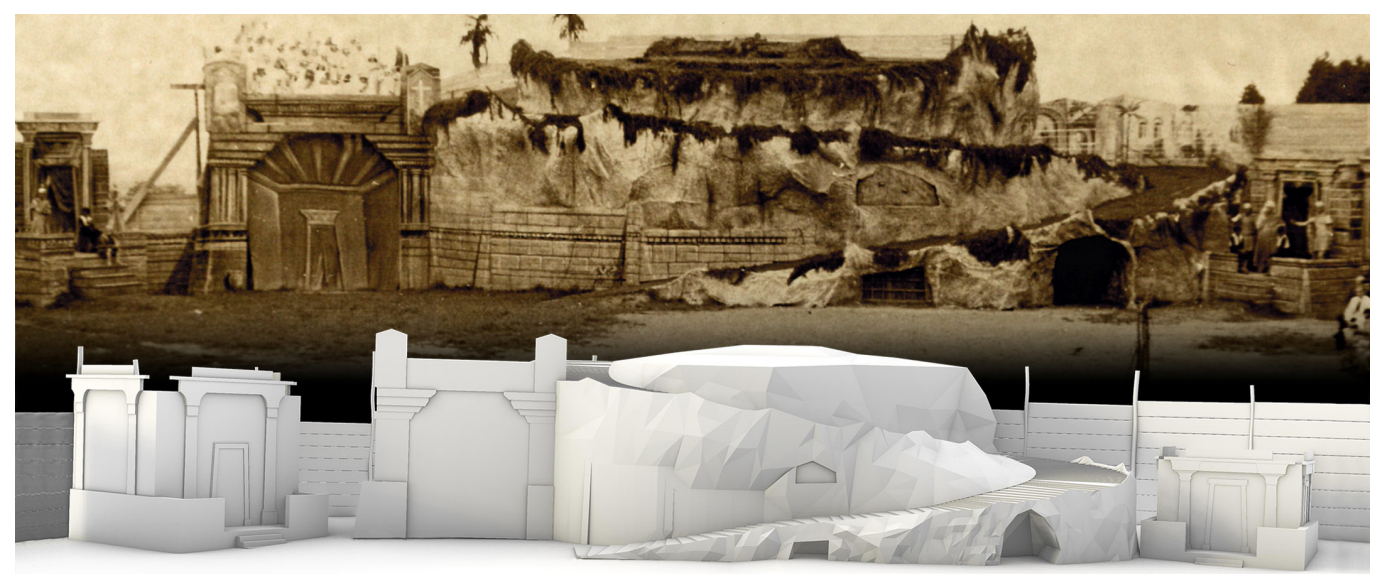

Fig. 10. Comparison between photographic image and conceptual reconstruction (1950) Anne, Entrance gate of Anna, Entrance gate for Calvary, Chair of Caiphas. 
Fig. II. Synthetic constructed for thents Passion play (1950). correct perception of the space and of the relationship between the elements of the scene and the audience, the reconstructions are initially visualized from a bird's eye view; subsequently, the camera moves at human height inside the stage perimeter, pausing on the most significant shots that characterize the two different theatrical performances. The characterizing elements have been identified by the analysis of the archival sources (Orsi 2000) such as the writing of Pinotto [2], a well-known local scholar. In 1934 Pinotto followed the show several times and noted positive and negative criticisms: this work was very precious for the managment of the performances of the following editions.

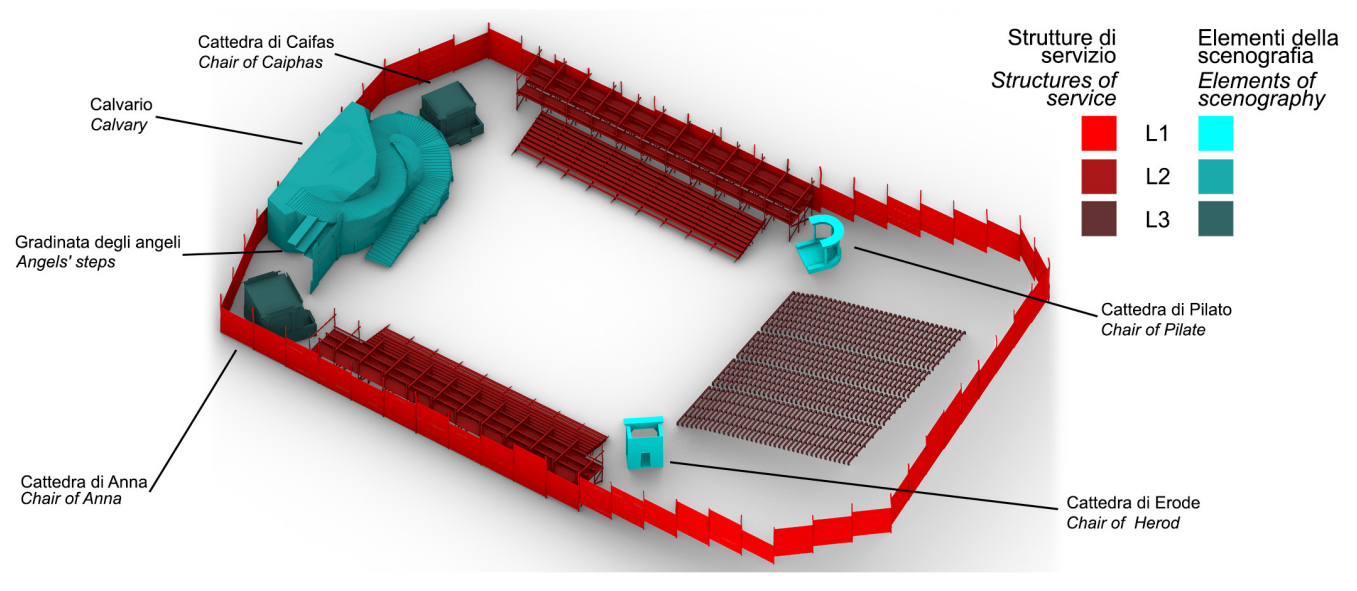

\section{Conclusions}

The described results represent a first important outcome of the research activity started between the Politecnico di Torino and the Museo della Passione of Sordevolo. Future activities will include the digitization of the archival sources and the development of a semantic organization of the contents, structured according to different levels of knowledge and made available also in remote mode.

In this regard, the new technologies can be useful not only to the reorganization of museum layouts, but also to the indispensable revision of the narratives connected to museum collections in order to satisfy the expectation of evolution of the narrative that is almost always denied so far [Orsini 2019]. According to Luigini, "when the output of an activity is the production of a tangible work, this brings with it a series of visible and invisible connections with other elements of the experience that constitute the actual added value of that product. It is precisely this process that allows cultural heritage artefacts to transmit information, knowledge, emotions, transforming themselves over time and resemantizing themselves." [Luigini 2018, p. 23].

Lampis himself emphasizes the need for a prudent rigor in their application so as not to run the risk of a simplification that could border on banalization. What is needed, therefore, is a hand (and a mind) capable of managing the countless modalities offered by modern technology, orienting the choices in the design of new forms of cultural fruition (fig. I2). In this regard, on the opening of the temporary exhibition named Invisible Archaeology (2019) at the Museo Egizio di Torino, the director reflected on the role of the museum: "The changes will continue. We will think of different organizational and architectural solutions responding to contemporary needs. There will certainly also be new forms of cultural enjoyment. Our task, however, will always be to improve the visual, aesthetic and intellectual experience of every visitor who comes, and to provide the necessary information to enrich their understanding. So the future of museums is, as it has always been, research" [Greco 2019, p. 20]. And we can only agree with him. 
Fig. 12. The performance of the Passion recited by the children (Archivio Passione 2010). Credits: Photo Perini Biella.

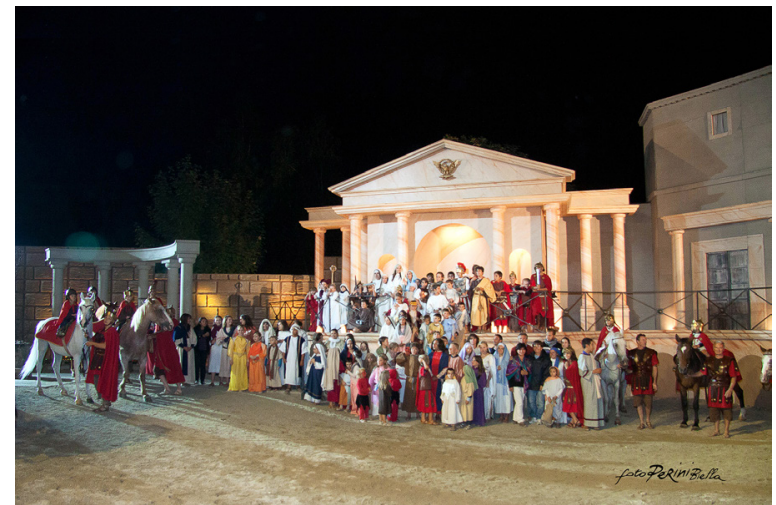

Notes

[I] UNESCO, Executive Board. Decisions adopted by the Executive Board at its 154th Session (Paris, 27 April-7 May 1998), 3.5 Culture , 3.5.I Proposal by the Director-General concerning the criteria for the selection of spaces or forms of popular and traditional cultural expression that deserve to be proclaimed by UNESCO to be masterpieces of the oral heritage of humanity (I54 EX/I3 and I54 EX/52) pp. I4, I5 ttp://unesdoc.unesco.org/images/00 I I/00 I I 20/ I I 20 I 9e.pdf (consultato il 20 marco 2021).

[2] Pinotto (1934). In Memory of the Passion of N.S.G.C. represented in Sordevolo in the year MCMXXXIV (XII E.F.)

\section{References}

Associazione Teatro Popolare di Sordevolo (20 I5). La Passione di Sordevolo. Immagini e parole. Gaglianico (BI): Botalla Editore.

Alivizatou M. (2007). The UNESCO programme for the Proclamation of Masterpieces of the Oral and Intangible Heritage of Humanity: A critical examination. In Journal of Museum Ethnography. n. 19, pp. 34-42.

Bianchini C., Nicastro S. (2018). La definizione del Level of Reliability: un contributo alla trasparenza dei processi di Historic-BIM. In Dn - Building Information Modeling, Data \& Semantics. n. 2, pp. 45-59.

Bonacini E. (2020). I musei e le forme dello storytelling digitale. Roma:Aracne.

Bortolotto C. (2007). From Objects to Processes: UNESCO'S' Intangible Cultural Heritage'. In Journal of Museum Ethnography. n. 19, pp. $21-33$.

Gabellone F. (2020). Archeologia virtuale. Teoria, tecniche e casi di studio. Lecce: Edizioni Grifo.

Greco C. (2019). La biografia degli oggetti. Rivoluzione digitale e Umanesimo. In Ciccopiedi C. (a cura di). Archeologia invisibile. Catalogo della mostra. Modena: Franco Cosimo Panini Editore.

Gütermann C. F. (2019). Sordevolo. Dove la Passione opera. Gaglianico (BI): Botalla Editore.

Luigini A., Panciroli C. (20|8). Ambienti digitali per l'educazione all'arte e al patrimonio. In Luigini A., Panciroli C. (a cura di) (20 18). Ambienti digitali per l'educazione all'arte e al patrimonio. Milano: Franco Angeli, pp. 17-32.

Orsi D. (2000). La Passione di Sordevolo. Studio di drammatica popolare. Torino: Omega Edizioni.

Orsini A., Lampis A. (2019). Piano Triennale per la Digitalizzazione e l'Innovazione dei Musei. Mibac, Direzione Generale Musei. <http://musei.beniculturali.it/wp-content/uploads/2019/08/Piano-Triennale-per-la-Digitalizzazione-e-l'Innovazione-dei-Musei. pdf> (accessed 2021, February 9).

UNESCO (1989). Recommendation on the Safeguarding of Traditional Culture and Folklore: <http://portal.unesco.org/en/ev.php-

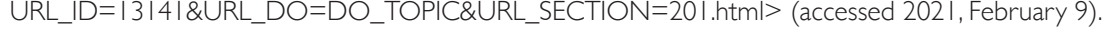

UNESCO Masterpieces of the Oral and Intangible Heritage of Humanity: Proclamations 2001, 2003 and 2005: <https://unesdoc. unesco.org/ark:/48223/pf0000147344> (accessed 2021, February 9).

Viola F., Cassone V. I. (20 I7). L'arte del coinvolgimento: emozioni e stimoli per cambiare il mondo. Milano: Hoepli Editore.

\section{Authors}

Massimiliano Lo Turco, Politecnico di Torino, massimiliano.loturco@polito.it

Elisabetta Caterina Giovannini, Politecnico di Torino, elisabettacaterina.giovannini@polito.it

Andrea Tomalini, Politecnico di Torino, andrea.tomalini@polit.it

To cite this chapter. Lo Turco Massimiliano, Giovannini Elisabetta Caterina, Tomalini Andrea (202I). Valorizzazione del patrimonio immateriale attraverso le tecnologie digitali: la Passione di Sordevolo/Enhancing intangible heritage trough digital technologies: La Passione di Sordevolo. In Arena A., Arena M. Mediati D. Raffa P. (a cura di). Connettere. Un disegno per annodare e tessere. Linguaggi Distanze Tecnologie. Atti del $42^{\circ}$ Convegno Internazionale dei Docenti delle Discipline della Rappresentazione/Connecting. Drawing for weaving relationship. Languages Distances Technologies. Proceedings of the $42^{\text {th }}$ International Conference of Representation Disciplines Teachers. Milano: FrancoAngeli, pp. $1689-1708$. 